\title{
Synthesis and Structure of the Hypermodified Nucleoside of Rat Liver Phenylalanine Transfer Ribonucleic Acid
}

\author{
Taisuke ITAYA* and Tae Kanai \\ Faculty of Pharmaceutical Sciences, Kanazawa University; Takara-machi, Kanazawa 920-0934, Japan. \\ Received April 10, 2002; accepted June 26, 2002
}

The first synthesis of $(\alpha S, \beta S)-\beta$-hydroxy- $\alpha$-[(methoxycarbonyl)amino]-4,6-dimethyl-9-oxo-3- $\beta$-D-ribofuranosyl-4,9-dihydro-3H-imidazo[1,2-a]purine-7-butanoic acid methyl ester $[(\alpha S, \beta S)-11]$ has been achieved by $\mathrm{OsO}_{4}$ oxidation of $[S$ - $(E)]-4-[4,6$-dimethyl-9-oxo-3-[2,3,5-tris- $O$-(tert-butyldimethylsilyl)- $\beta$-D-ribofuranosyl]-4,9dihydro-3H-imidazo[1,2-a]purin-7-yl]-2-[(methoxycarbonyl)amino]-3-butenoic acid methyl ester (13) followed by successive $\gamma$-deoxygenation through the cyclocarbonates, separation from the $(\alpha S, \beta R)$-isomer by means of flash chromatography, and deprotection. On the other hand, the minor nucleoside of rat liver tRNA ${ }^{\text {Phe }}$ was isolated on a scale of $100 \mu \mathrm{g}$ by partial digestion of unfractionated tRNA $(1 \mathrm{~g})$ with nuclease $P_{1}$, followed by reverse-phase column chromatography, complete digestion with nuclease $P_{1}$ /alkaline phosphatase, and reverse-phase HPLC. Comparison of this nucleoside with the synthetic one has unambiguously established its structure to be $(\alpha S, \beta S)$ 11.

Key words $\beta$-hydroxywybutosine; minor nucleoside; rat liver tRNA ${ }^{\text {Phe }}$; fluorescent nucleoside; condensed tricyclic nucleoside

Many eukaryotic tRNAs ${ }^{\text {Phe }}$ have fluorescent components at the position next to the $3^{\prime}$-end of the anticodon. ${ }^{1-5)}$ The fluorescent base isolated from chicken, rat, and bovine liver tRNAs $^{\text {Phe }}$ was first reported to be $\beta$-hydroperoxywybutine $(3)^{6,7)}$ on the basis of comparison of the UV, fluorescent, and MS spectra as well as the chromatographic behavior with those of wybutine $(\mathbf{1}),{ }^{8,9)}$ the structurally related precedent from yeast tRNA ${ }^{\text {Phe }}$. The base from the plant Lupinus luteus was also characterized as $3{ }^{10)}$ In this case, the presence of the hydroperoxy group was supported by a specific color test employing $\mathrm{Fe}(\mathrm{SCN})_{2}$. The structure 3 was suggested to be assigned to the base from wheat germ tRNA ${ }^{\text {Phe }},{ }^{10)}$ because it had been shown to be indistinguishable from that of beef. ${ }^{11)}$ Kasai et al., however, reported that the fluorescent base from rat liver tRNA ${ }^{\text {Phe }}$ was $\beta$-hydroxywybutine (2) on the basis of the MS spectral data as well as the negative coloring test for the hydroperoxy group. ${ }^{12)}$ Those authors proposed that $\mathbf{3}$ might be an artifact formed during storage of the sample of $\mathbf{2}$ and suggested that the base from wheat germ tRNA ${ }^{\text {Phe }}$ was also 2. Notwithstanding that report, Mochizuki et al. preferred 3 for the fluorescent base isolated from the aquatic fungus Geotrichum candidum tRNA ${ }^{\text {Phe }}{ }^{13)}$ Wiewiórowski's group also reported that the base from tRNAs ${ }^{\text {Phe }}$ of wheat germ, yellow lupine seeds, and maize seeds was 3 . They described $\mathbf{3}$ as very unstable and found that it decomposed to $\mathbf{2}$ and $\mathbf{1}^{14)}$ : The stability observed for $\mathbf{2}$ and $\mathbf{3}$ contradicted that reported by Kasai et al. ${ }^{12)}$ Although we achieved the synthesis of $(\alpha S, \beta R)$ - and $(\alpha S, \beta S)-2$ as the most probable alternatives for the base isolated from rat liver tRNA ${ }^{\text {Phe }}$, 315,16 ) the lack of a sample of the base from the tRNA ${ }^{\text {Phe }}$ has hampered its structural determination. In the present investigation, we

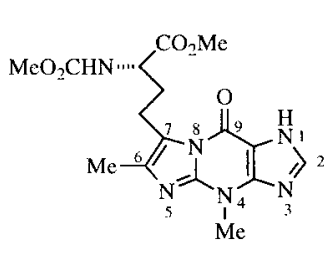

1

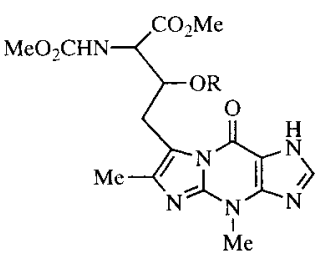

2: $\mathrm{R}=\mathrm{H}$ 3: $\mathrm{R}=\mathrm{OH}$ isolated the corresponding nucleoside from rat liver for the first time and determined its structure to be $(\alpha S, \beta S)$-11, the first synthesis of which is also described. A preliminary communication of this work has been published. ${ }^{17,18)}$

\section{Results and Discussion}

Synthesis The synthesis of the bases $(\alpha S, \beta R)$ - and $(\alpha S, \beta S)-2$ has been accomplished by $\mathrm{OsO}_{4}$ oxidation of the olefin 4 followed by separation of the resulting diastereomers 5 and 7 and hydrogenolysis through the cyclic carbonates 6 and $\mathbf{8}$, as shown in Chart $1 ., 15,16)$ In the present study, we first examined the applicability of this reaction sequence to the nucleoside level. Thus the Heck reaction between $2^{\prime}, 3^{\prime}, 5^{\prime}$-tri$O$-acetyl-7-iodowyosine (9) ${ }^{19)}$ and ( \pm )-2-[(methoxycarbonyl)amino]-3-butenoic acid ${ }^{20)}$ was conducted according to the procedure reported for the synthesis of 3 - $\beta$-D-ribofuranosylwybutine (12). ${ }^{19)}$ The product was treated with $\mathrm{Me}_{3} \mathrm{SiCHN}_{2}$ to give a mixture of diastereomers 10. This was subjected to $\mathrm{OsO}_{4}$ oxidation followed by cyclocondensation with triphosgene, catalytic hydrogenolysis, purification by preparative TLC, and deprotection to afford a mixture of four diastereomers 11, as shown in Chart 2. These were separated by HPLC. Two were $(\alpha S, \beta R)$ - and $(\alpha S, \beta S)-\mathbf{1 1}$, of which unambiguous syntheses are described below. The structures of the others $[(\alpha R, \beta S)$ - and $(\alpha R, \beta R)-11]$ were assignable by comparison of the ${ }^{1} \mathrm{H}-\mathrm{NMR}$ patterns of their amino acid moieties with those of $(\alpha S, \beta R)$ - and $(\alpha S, \beta S)-11$. Assuming that 2 is the correct two-dimensional expression of the structure of the hypermodified base of rat liver tRNA ${ }^{\text {Phe }}$, one of the four diastereomers $\mathbf{1 1}$ is likely the correct structure of the corresponding nucleoside. We preferred $(\alpha S, \beta R)-11$ and $(\alpha S, \beta S)-11$ as the most probable alternatives because structurally related wybutosine (12) from yeast tRNA ${ }^{\text {Phe }}$ had been determined by us to have the $(\alpha S)$ configuration. ${ }^{2)}$

Because it is difficult to obtain stereochemically pure $(\alpha S)$-10 in a large quantity ${ }^{19)}$ we selected $\mathbf{1 3}^{2)}$ as a key intermediate for the stereospecific synthesis of $(\alpha S, \beta R)$ - and $(\alpha S, \beta S)-11 . \mathrm{OsO}_{4}$ oxidation of the olefin 13 in the presence of $N$-methylmorpholine $N$-oxide in acetone-phosphate buffer (pH 6) at room temperature, followed by HPLC on silica gel 


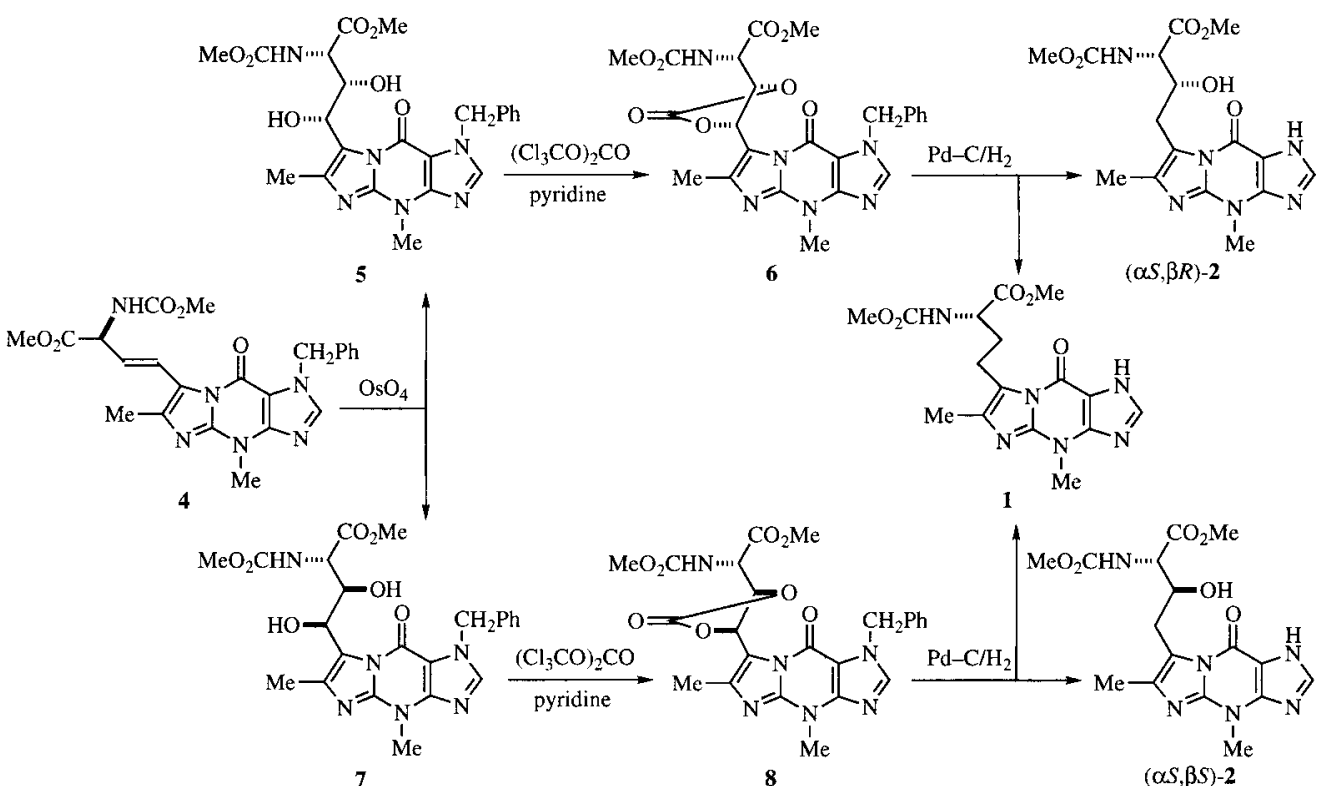

Chart 1
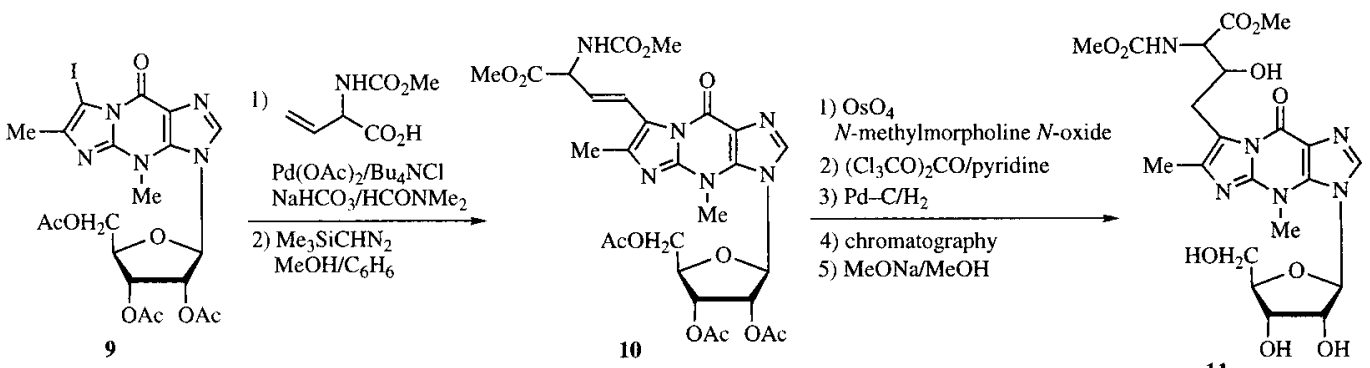

Chart 2

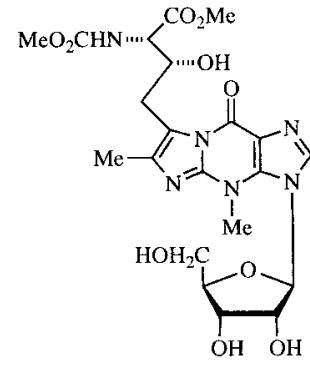

$(\alpha S, \beta R)-11$

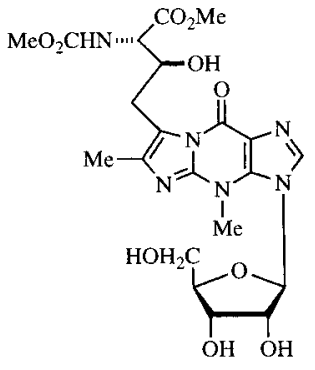

$(\alpha S, \beta S)-11$

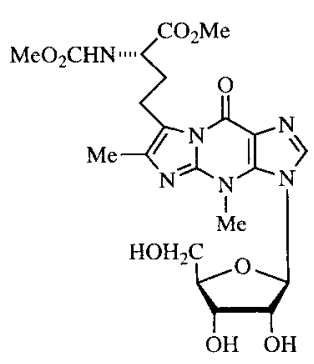

12 afforded the diols $\mathbf{1 4}$ and $\mathbf{1 6}$ in 51\% and 30\% yields, respectively. The configurations of these compounds were assignable by comparison of their ${ }^{1} \mathrm{H}-\mathrm{NMR}$ spectra with those of the bases 5 and 7. ${ }^{3)}$ Treatment of the major isomer 14 with an excess of triphosgene in $\mathrm{CH}_{2} \mathrm{Cl}_{2}$ in the presence of pyridine at $0{ }^{\circ} \mathrm{C}$ afforded the cyclic carbonate 15 in $80 \%$ yield. Catalytic hydrogenolysis of $\mathbf{1 5}$ over Pearlman's catalyst afforded the $\beta$ hydroxy compound $\mathbf{1 7}$ in $28 \%$ yield together with the dideoxy compound $\mathbf{1 8}$ (2) $(23 \%)$. The analogous concomitant formation of the dideoxy compounds has already been recognized in the reaction of the model compound $( \pm)-\mathbf{1 9}^{3,16)}$ and in the reactions involved in Charts 1,2. As illustrated in Chart 4, hydrogenolysis of $( \pm)$-19 should produce the intermediate 20. While hydrolysis of the hydrogen carbonate $\mathbf{2 0}$ would provide the desired monohydroxy compound 21, elimination of $\mathrm{H}_{2} \mathrm{CO}_{3}$ followed by hydrogenation would form the dideoxy compound 23 through the olefin 22. Analogous examples of the formation of saturated compounds and olefins have already been reported for the electrochemical reduction of cyclic carbonates of meso-hydrobenzoin, ( \pm )-hydrobenzoin, and (E)-2,3-diphenylbutane-1,2-diol. ${ }^{21)}$ Although the undesirable dideoxygenation of ( \pm )-19 could be suppressed to some extent by the use of $\mathrm{Pt}$ instead of $\mathrm{Pd}-\mathrm{C},{ }^{16)}$ the Pt catalyst was found in the present investigation to be inferior in view of reproducibility for hydrogenolysis of $\mathbf{1 5}$. Deprotection of $\mathbf{1 7}$ was accomplished by treatment with $\mathrm{Bu}_{4} \mathrm{NF}$ in aqueous THF in the presence of pyridine at room temperature $^{22)}$ without cleaving the extraordinarily labile glycosyl 


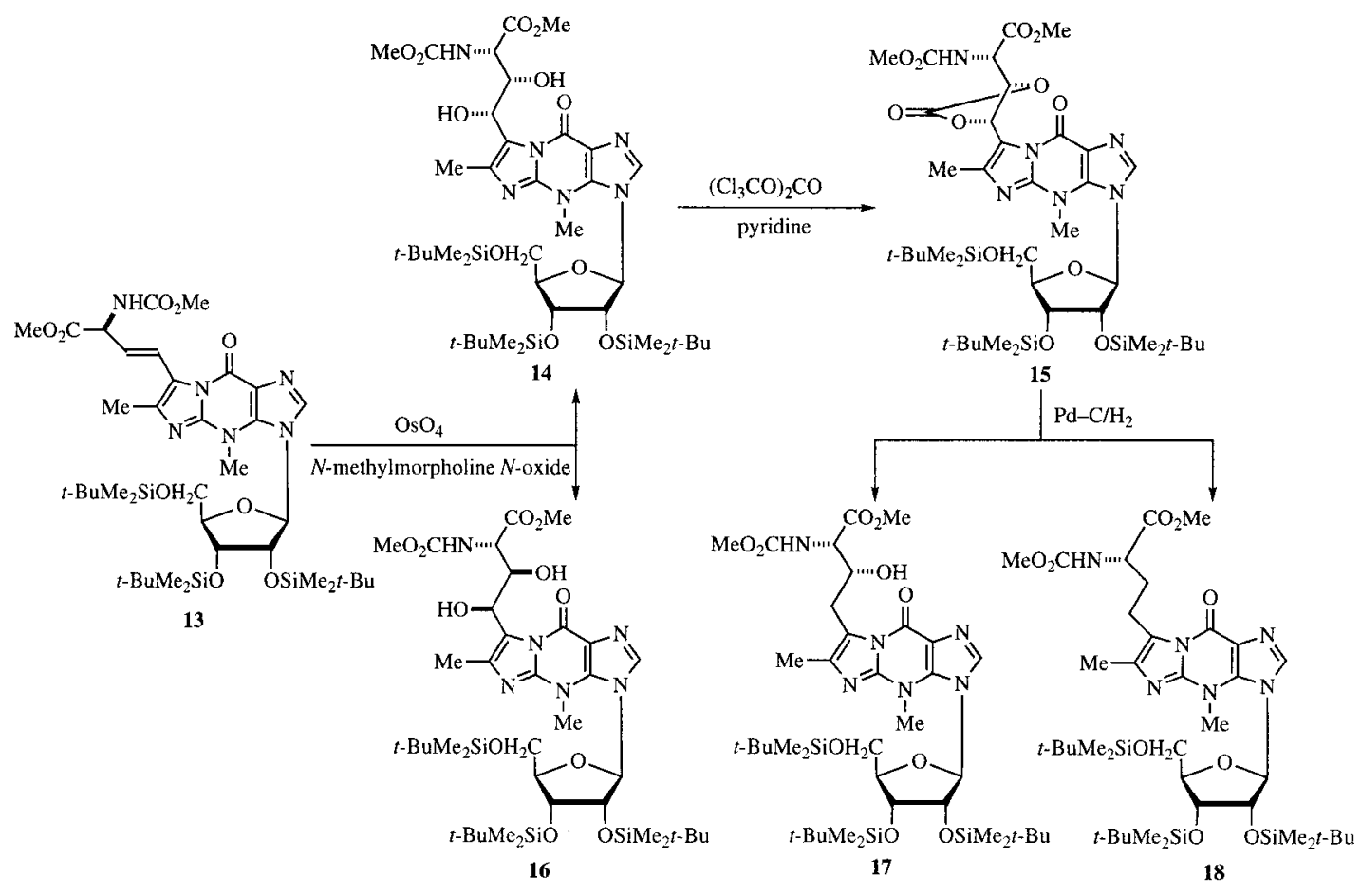

Chart 3

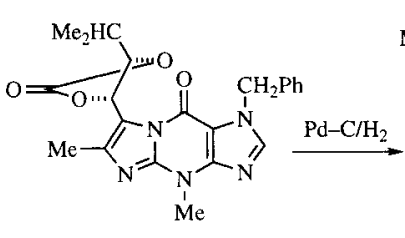

$( \pm)-19$

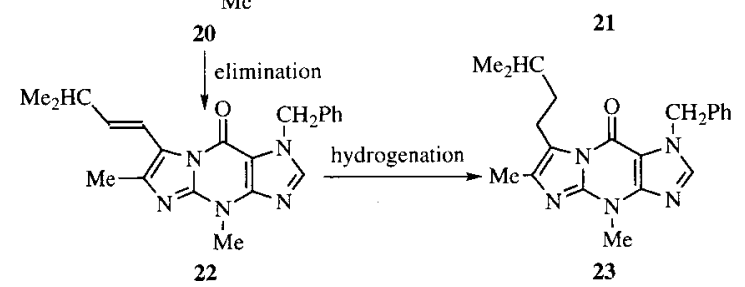

Chart 4

bond to provide the desired nucleoside in $86 \%$ yield. The correctness of the assignment of the structure $(\alpha S, \beta R)-11$ to this product was established by its hydrolysis with $0.1 \mathrm{~N}$ aqueous $\mathrm{HCl}$, leading to optically pure $(\alpha S, \beta R)-2$. The ${ }^{1} \mathrm{H}-$ NMR $\left[\left(\mathrm{CD}_{3}\right)_{2} \mathrm{SO}\right.$ or $\left.\left(\mathrm{CD}_{3}\right)_{2} \mathrm{CO}\right]$ spectral patterns of signals arising from the side chains of these two compounds closely resemble each other. This is also the case with the ${ }^{1} \mathrm{H}-\mathrm{NMR}$ spectra of 17 and $\left(R^{*}, S^{*}\right)$-1-benzyl- $\beta$-hydroxy- $\alpha$-[(methoxycarbonyl)amino]-4,6-dimethyl-9-oxo-4,9-dihydro- $1 H$-imidazo[1,2-a]purine-7-butanoic acid methyl ester $[( \pm)-24]^{16)}$ measured in $\mathrm{CDCl}_{3}$, as shown in Table 1. However, $(\alpha S, \beta R)$ 2 shows a somewhat different ${ }^{1} \mathrm{H}-\mathrm{NMR}$ spectrum from that of 17 in $\mathrm{CDCl}_{3}$ (Table 1), suggesting that $\mathrm{N}(1)$-H of $(\alpha S, \beta R)$ 2 affects the conformation of its side chain through hydrogen bonding in this solvent.

Contrary to the successful conversion of the diol 14 into the carbonate 15, the minor isomer 16 with $(\alpha S, \beta R, \gamma R)$ configurations did not produce the cyclic carbonate 26 at all upon treatment with triphosgene in a manner similar to that<smiles>CC(=O)N[C@@H](Cc1c(C)nc2n(C)c3ncn(Cc4ccccc4)c3c(=O)n12)[C@H](C)C(C)=O</smiles>

$( \pm)-24$<smiles>CC(=O)NC(Cc1c(C)nc2n(C)c3ncn(Cc4ccccc4)c3c(=O)n12)C(C)=O</smiles>

$( \pm)-25$ employed for the preparation of $\mathbf{1 5}$. The starting material $\mathbf{1 6}$ was recovered in $c a$. $80 \%$ yield. This is an unbelievably strange result in view of the positive reaction of the base $7^{3}$ ) (Chart 1) having the same configurations and the reaction of the $(\alpha S, \beta R, \gamma R)$-nucleoside involved in the reaction sequence shown in Chart 2. The latter case indicated what should be done to obtain the desired carbonate 26. When a mixture of 16 and 14, accessible in $91 \%$ yield in a ratio of $1: 2$ in the above $\mathrm{OsO}_{4}$ oxidation of $\mathbf{1 3}$, was subjected to the reaction with triphosgene, $\mathbf{2 6}$ was obtained as a mixture with $\mathbf{1 5}$ in a 
Table 1. ${ }^{1} \mathrm{H}-\mathrm{NMR}$ Spectral Data for $(\alpha S, \beta R)-,(\alpha S, \beta S)-2$, and Related Compounds Measured in $\mathrm{CDCl}_{3}{ }^{a)}$

\begin{tabular}{|c|c|c|c|c|c|c|c|}
\hline \multirow{3}{*}{ Proton } & \multicolumn{7}{|c|}{ Chemical shift $(\delta)$} \\
\hline & \multirow{2}{*}{$(\alpha S, \beta R)-\mathbf{2}^{b)}$} & \multirow{2}{*}{$17^{c)}$} & \multirow{2}{*}{$( \pm)-24^{d)}$} & \multicolumn{2}{|c|}{$(\alpha S, \beta S)-\mathbf{2}^{b)}$} & \multirow{2}{*}{$27^{c)}$} & \multirow{2}{*}{$( \pm)-25^{d}$} \\
\hline & & & & Species 1 & Species 2 & & \\
\hline \multirow[t]{2}{*}{$\mathrm{CO}_{2} \mathrm{CH}_{3}$} & $3.68 \mathrm{~s}$ & 3.72 & 3.74 & $3.69 \mathrm{~s}$ & $3.69 \mathrm{~s}$ & 3.70 & 3.72 \\
\hline & $3.73 \mathrm{~s}$ & 3.76 & 3.77 & $3.82 \mathrm{~s}$ & $3.87 \mathrm{~s}$ & 3.80 & 3.73 \\
\hline $\mathrm{C}(\alpha)-\mathrm{H}$ & $4.56 \mathrm{~d}(9.8)^{e)}$ & 4.46 & $4.49^{f)}$ & $4.78 \mathrm{~m}$ & $4.19 \mathrm{~m}$ & 4.50 & $4.52^{f)}$ \\
\hline $\mathrm{C}(\beta)-\mathrm{H}$ & $4.47 \mathrm{~m}$ & 4.39 & 4.37 & $4.27 \mathrm{~m}$ & $4.58 \mathrm{~m}$ & 4.16 & 4.15 \\
\hline \multirow{2}{*}{$\mathrm{C}(\gamma)-\mathrm{H}_{2}$} & $3.19 \mathrm{dd}(15.6,4.4)$ & 3.15 & 3.22 & $3.10 \mathrm{~m}$ & $3.44 \mathrm{dd}(15,10.7)$ & 3.41 & 3.36 \\
\hline & 3.75 dd $(15.6,8.8)$ & 3.57 & 3.46 & $3.70 \mathrm{~m}$ & $3.55 \mathrm{dd}(15,1.5)$ & & 3.41 \\
\hline $\mathrm{C}(\beta)-\mathrm{OH}$ & $4.94 \mathrm{~d}(5.9)^{g)}$ & 4.17 & 4.15 & $4.78 \mathrm{br}$ & $4.10 \mathrm{br}$ & 3.83 & 3.80 \\
\hline $\mathrm{C}(\alpha)-\mathrm{NH}$ & $6.39 \mathrm{~d}(9.5)^{h)}$ & 5.66 & $5.65^{f)}$ & $6.90 \mathrm{br}$ & $8.00 \mathrm{br}$ & 5.88 & $5.90^{f)}$ \\
\hline $\mathrm{C}(6)-\mathrm{CH}_{3}$ & $2.32 \mathrm{~s}$ & 2.25 & 2.27 & $2.26 \mathrm{~s}$ & $2.44 \mathrm{~s}$ & 2.25 & 2.26 \\
\hline $\mathrm{NCH}_{3}$ & $3.97 \mathrm{~s}$ & 4.11 & 3.92 & $3.95 \mathrm{~s}$ & $3.97 \mathrm{~s}$ & 4.11 & 3.90 \\
\hline $\mathrm{C}(2)-\mathrm{H}$ & $7.90 \mathrm{~s}$ & 7.94 & 7.66 & $7.93 \mathrm{~s}$ & $7.89 \mathrm{~s}$ & 7.94 & 7.66 \\
\hline $\mathrm{N}(1)-\mathrm{H}$ & $11.51 \mathrm{~s}^{i)}$ & - & - & $11.46 \mathrm{br}$ & $13.52 \mathrm{br}$ & - & - \\
\hline
\end{tabular}

a) Figures in parentheses denote coupling constants $(J)$ in Hz. $b$ ) Measued for a $2.4 \mathrm{~mm}$ solution. $c$ ) See Experimental for complete data. $d$ ) Taken from ref. 16 . e) Accompanied by a small broad signal at 4.35. $f$ ) Accompanied by a minor signal. $g$ ) Accompanied by a small broad signal at 5.03 . $h$ ) Accompanied by a small broad signal at 6.29 . i) Accompanied by a small broad signal at 11.74 .

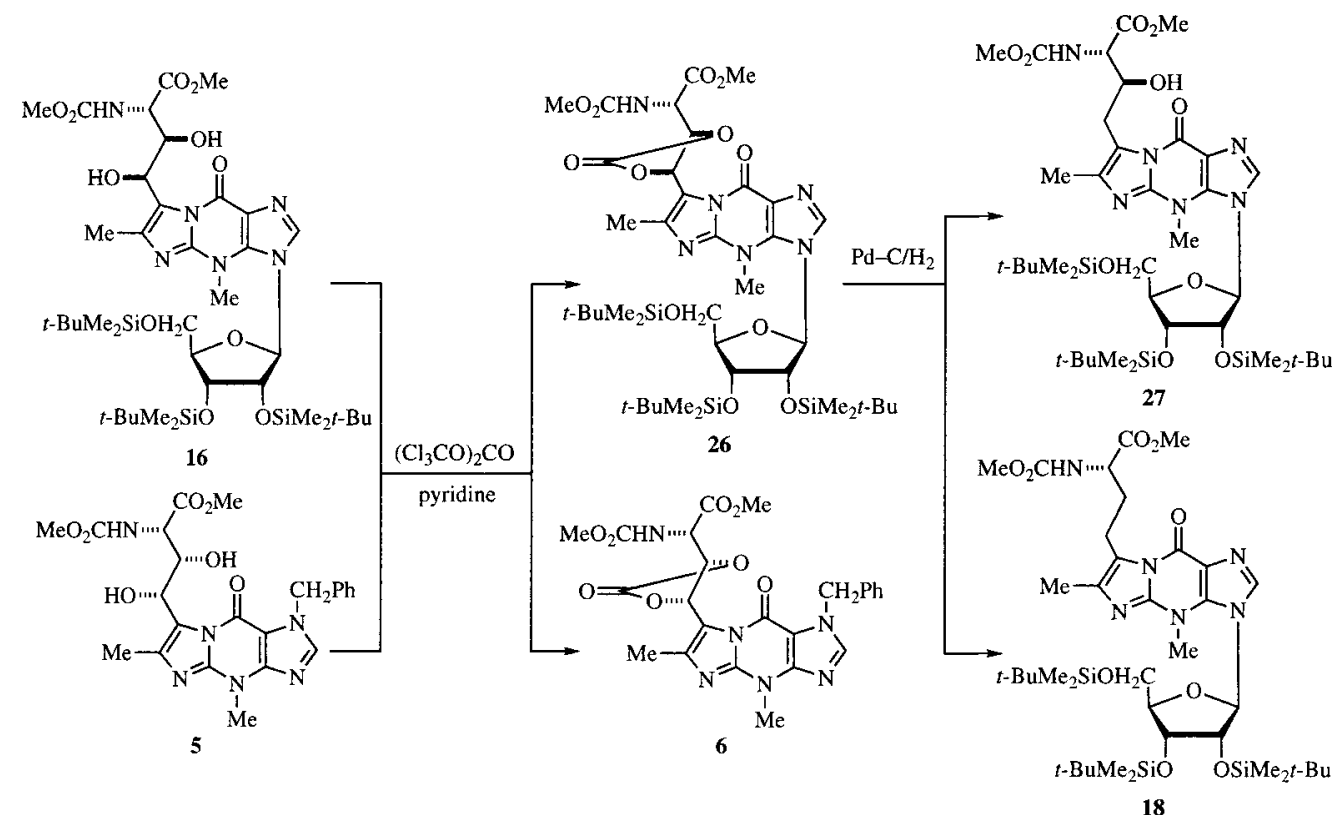

Chart 5

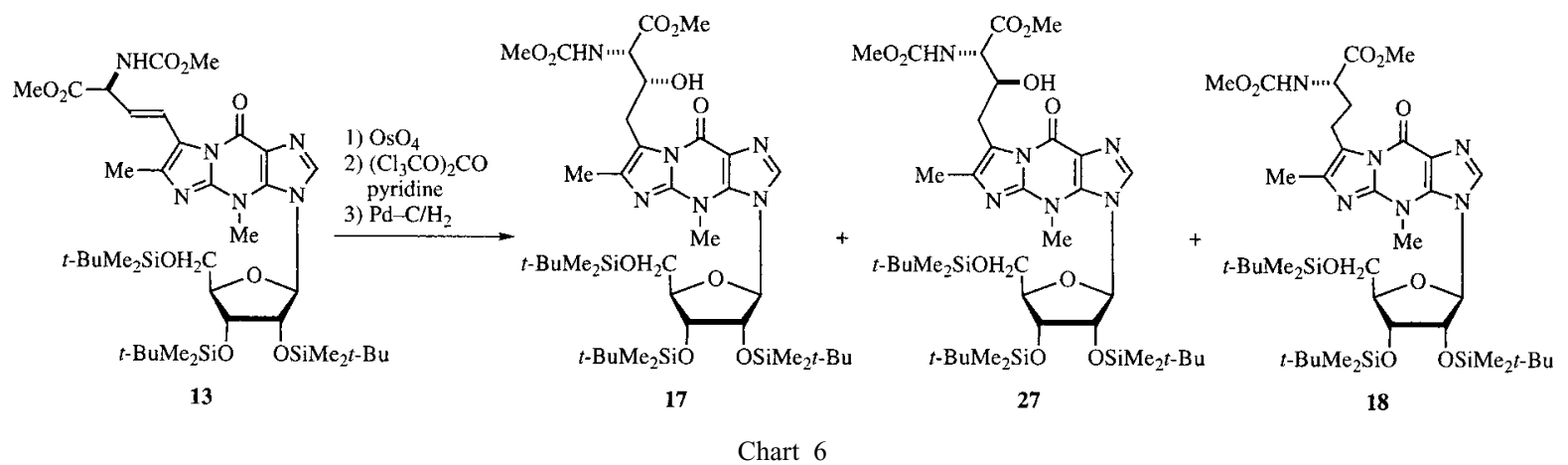

ratio of $1: 2.9$. However, 26 was not formed when $\mathbf{1 6}$ was added after the reaction of $\mathbf{1 4}$ with triphosgene was completed even in the presence of excess reagents. These results suggest that an intermolecular interaction between the side chains of $\mathbf{1 4}$ and $\mathbf{1 6}$ is important for the cyclocondensation of 16. Although separation of the mixture of $\mathbf{1 5}$ and $\mathbf{2 6}$ was difficult, 16 underwent cyclocondensation as well with triphosgene in the presence of the base 5 having the $(\alpha S, \beta S, \gamma S)$ 
configurations, giving a mixture of the carbonates (26 and $\mathbf{6}$ ) as shown in Chart 5 . Compound $\mathbf{2 6}$ was easily obtained from this mixture by flash chromatography in $57 \%$ yield. Hydrogenolysis of $\mathbf{2 6}$ using Pearlman's catalyst afforded the monohydroxy compound $\mathbf{2 7}$ in 39\% yield together with the dideoxy compound $18(19 \%)$. As the two diastereomers 17 and 27 can be separated by flash chromatography, these were more conveniently obtained by hydrogenolysis of the $1: 2.9$ mixture of $\mathbf{1 5}$ and $\mathbf{2 6}$ described above in $21 \%$ and $8 \%$ yields, respectively, based on the olefin $\mathbf{1 3}$ (Chart 6). Desilylation of 27 afforded $(\alpha S, \beta S)-11$ in $86 \%$ yield. Hydrolysis of $(\alpha S, \beta S)-11$ produced optically pure $(\alpha S, \beta S)-2$ in $98 \%$ yield.

It should be noted that the ${ }^{1} \mathrm{H}-\mathrm{NMR}$ spectrum arising from the side chain of the base $(\alpha S, \beta S)$-2 in $\mathrm{CDCl}_{3}$ does not resemble those of $( \pm)-\mathbf{2 5}^{16)}$ and 27. Interestingly, $(\alpha S, \beta S)-2$ shows two sets of signals (species 1 and 2 in Table 1 ) in $\mathrm{CDCl}_{3}$, while the diastereomer $(\alpha S, \beta R)-2$ exists as a single species. This complexity of the signals disappeared in the spectra taken in $\left(\mathrm{CD}_{3}\right)_{2} \mathrm{SO},{ }^{3)}\left(\mathrm{CD}_{3}\right)_{2} \mathrm{CO}, \mathrm{CD}_{3} \mathrm{CN}$, and pyridine- $d_{5}$, all of which are stronger hydrogen bond acceptors than $\mathrm{CDCl}_{3}$. Furthermore, the molar ratio of the two species estimated on the basis of relative areas of the C(6)-Me signals depended on the total concentration, as shown in Table 2 . These results suggest that $(\alpha S, \beta S)$-2 molecules associate themselves in part through intermolecular hydrogen bond(s) in $\mathrm{CDCl}_{3}$.

Compounds $(\alpha S, \beta R)$ - and $(\alpha S, \beta S)-\mathbf{1 1}$ thus obtained were converted into their tetraacetates- $d_{12} \mathbf{2 8}$ and $\mathbf{2 9}$ according to the strategy that we had used to determine the structures of wyosine $^{1)}$ from torula yeast tRNA and wybutosine $(\mathbf{1 2})^{2)}$ from baker's yeast tRNA. Compounds $\mathbf{2 8}$ and $\mathbf{2 9}$ could be distinguished by comparison of their ${ }^{1} \mathrm{H}-\mathrm{NMR}$ spectra taken in $\mathrm{CDCl}_{3}$.

Isolation and Identification of the Minor Nucleoside and Its Base from Rat Liver tRNA We had already determined the structures of wyosine ${ }^{1)}$ and wybutosine $(\mathbf{1 2})^{2)}$ by

Table 2. Effect of Total Concentrations on Ratios of Two Species of $(\alpha S, \beta S)-\mathbf{2}$ in $\mathrm{CDCl}_{3}$ as Determined by ${ }^{1} \mathrm{H}$-NMR Spectroscopy

\begin{tabular}{cc}
\hline \hline $\begin{array}{c}\text { Total concentration of }(\alpha S, \beta S)-\mathbf{2} \\
(\mathrm{mm})\end{array}$ & $\begin{array}{c}\text { Mole fraction of species } 1^{a)} \\
(\%)\end{array}$ \\
\hline 0.038 & 81 \\
0.075 & 71 \\
0.15 & 63 \\
0.30 & 59 \\
0.60 & 52 \\
1.2 & 49 \\
2.4 & 46 \\
\hline
\end{tabular}

a) Estimated on the basis of relative areas of the $\mathrm{C}(6)$-Me signals of the two species. isolating these nucleosides on a scale of $70-80 \mu \mathrm{g}$. To determine how many rats are required for isolation of a comparable amount of the target nucleoside, we first attempted isolation of the corresponding base as a preliminary experiment. Unfractionated tRNA obtained from the livers of $c a .10$ rats was subjected to mild acid treatment ${ }^{23)}\left(\mathrm{pH} 2.9\right.$ at $40^{\circ} \mathrm{C}$ for $16 \mathrm{~h}$ ), and polynucleotides were removed by precipitation with EtOH. The minor base was obtained on a scale of a few micrograms from the soluble part by means of TLC on silica gel. The HPLC behavior of the base thus obtained was identical with that ${ }^{3)}$ of $(\alpha S, \beta S)-2$, and the correctness of its absolute configurations was established by chiral HPLC analysis. Furthermore, the assignable signals appearing in the ${ }^{1} \mathrm{H}-$ NMR spectrum $\left[\left(\mathrm{CD}_{3}\right)_{2} \mathrm{CO}\right]$ of this compound corresponded to those of $(\alpha S, \beta S)-2$. No trace of wybutine (1) was detected in contrast to the results reported by Kasai et al. ${ }^{12)}$ It follows that $(\alpha S, \beta S)-2$ is unlikely to be an artifact of hydroperoxywybutine (3), because 3 was reported to decompose to 2 and 1. ${ }^{14)}$ Thus we concluded that the formula $(\alpha S, \beta S)-2$ is a complete expression of the hypermodified base of rat liver tRNA $^{\text {Phe }}$. It should be noted that $(\alpha S, \beta S)$-2 was stable during storage at room temperature, contrary to the contention of Kasai et al. ${ }^{12}$

To isolate the nucleoside on a scale of some $50 \mu \mathrm{g}$, we next started with the same grade of tRNA $(1 \mathrm{~g})$ obtained from 100 rats. Because this material resisted digestion with nuclease $\mathrm{P}_{1}$, it was extracted with aqueous $\mathrm{Me}_{2} \mathrm{CHOH}$ and then with $\mathrm{H}_{2} \mathrm{O}$. The tRNA in the combined solution was purified by ion-exchange chromatography to give unfractionated tRNA $\left(350 \mathrm{mg}\right.$ ). This was partially digested with nuclease $P_{1}$ followed successively by reverse-phase column chromatography, complete digestion with nuclease $\mathrm{P}_{1}$, dephosphorylation with alkaline phosphatase, and HPLC according to the reported procedure ${ }^{1,2)}$ to give the target nucleoside $(100 \mu \mathrm{g})$. We did not find any trace of wybutosine (12). The HPLC behavior of the nucleoside was identical to that of $(\alpha S, \beta S)-\mathbf{1 1}$ but different from that of the diastereomer $(\alpha R, \beta R)$-11, ruling out the 3- $\beta$-L-ribofuranosyl structure 30 for this nucleoside because $(\alpha R, \beta R)-\mathbf{1 1}$ is the enantiomer of $\mathbf{3 0}$. The minor nucleoside thus obtained was converted into the tetraacetate$d_{12}$, which was identical to $\mathbf{2 9}$ on the basis of MS and ${ }^{1} \mathrm{H}$ NMR spectroscopy. Finally the tetraacetate- $d_{12}$ of natural origin was treated with $\mathrm{MeONa}-\mathrm{MeOH}$ and then with dilute aqueous $\mathrm{HCl}$ to give the base, the identity of which with $(\alpha S, \beta S)$-2 was confirmed by comparison of their HPLC behavior and ${ }^{1} \mathrm{H}-\mathrm{NMR}$ spectra. The structure of the hypermodified nucleoside of rat liver tRNA ${ }^{\text {Phe }}$ was hereby determined unambiguously to be $(\alpha S, \beta S)-\mathbf{1 1}$.

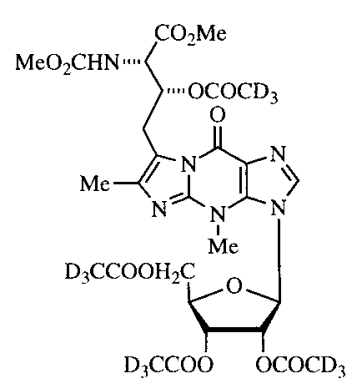

28

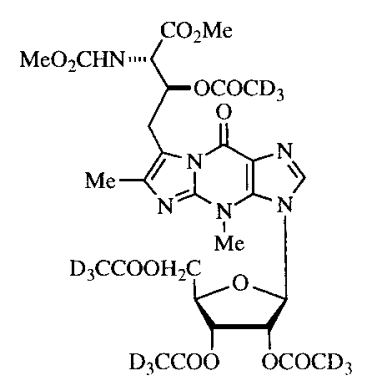

29

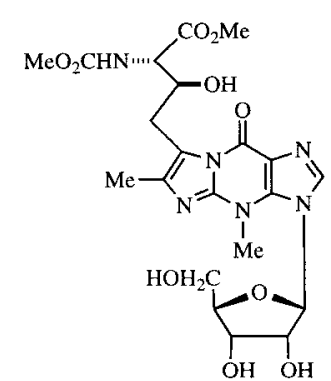

30

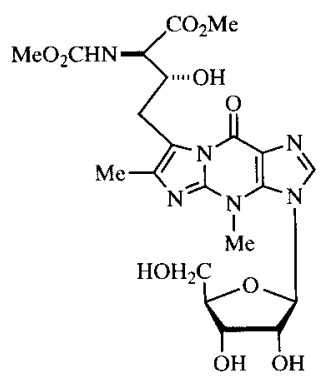

$(\alpha R, \beta R)-11$ 


\section{Experimental}

General Notes Spectra reported herein were recorded on a JEOL JMSSX102A mass spectrometer, a Hitachi U-3010 spectrophotometer, or a JEOL JNM-GSX-500 NMR spectrometer (measured at $25^{\circ} \mathrm{C}$ with $\mathrm{Me}_{4} \mathrm{Si}$ as an internal standard unless otherwise stated). $\mathrm{CDCl}_{3}$ for measurements of small samples was treated with alumina according to the reported procedure. ${ }^{1)}$ MS measurements were performed by Dr. M. Takani and her associates at Kanazawa University. The optical rotation was measured with a Horiba SEPA-300 polarimeter using a $10-\mathrm{cm}$ sample tube. The HPLC system employed consisted of a Tosoh CCPD pump, an injection valve unit, a UV-8020 detector, and a Chromatocorder 21 integrator or a Waters 6000A pump, a U6K injector, and a model 440 absorbance detector. The following abbreviations are used: $\mathrm{br}=$ broad, $\mathrm{d}=$ doublet, $\mathrm{dd}=$ doublet-of-doublets, ddd = doublet-of-doublets-of-doublets, dddd= doublet-of-doublets-of-doublets-of-doublets, $\mathrm{ddt}=$ doublet-of-doublets-of-triplets, $\mathrm{m}=$ multiplet, and $\mathrm{s}=$ singlet.

Synthesis of Four Diastereomers of $\boldsymbol{\beta}$-Hydroxy-3- $\boldsymbol{\beta}$-D-ribofuranosylwybutine (11) A mixture of $\mathrm{Pd}(\mathrm{OAc})_{2}(6.6 \mathrm{mg}, 0.029 \mathrm{mmol}), \mathrm{NaHCO}_{3}$ (201 mg, $2.39 \mathrm{mmol}), 9^{19)}$ (468 mg, $\left.0.797 \mathrm{mmol}\right), \mathrm{Bu}_{4} \mathrm{NCl}(222 \mathrm{mg}, 0.799$ $\mathrm{mmol}$ ), and $\mathrm{Me}_{2} \mathrm{NCHO}(12 \mathrm{ml})$ was stirred at $60^{\circ} \mathrm{C}$ for $10 \mathrm{~min}$. (土)-2[(Methoxycarbonyl)amino]-3-butenoic acid $^{20)}(191 \mathrm{mg}, 1.20 \mathrm{mmol})$ was added to the mixture, and the whole was stirred at $60-65^{\circ} \mathrm{C}$ for $8 \mathrm{~h}$. After $\mathrm{H}_{2} \mathrm{O}(30 \mathrm{ml})$ was added, the resulting mixture was brought to $\mathrm{pH} 3$ by the addition of $10 \%$ aqueous $\mathrm{H}_{3} \mathrm{PO}_{4}$ and extracted with $\mathrm{CHCl}_{3}(2 \times 30 \mathrm{ml})$. The organic layers were combined and extracted with saturated aqueous $\mathrm{NaHCO}_{3}$ $(3 \times 20 \mathrm{ml})$. The aqueous layers were combined, brought to $\mathrm{pH} 3$ with $10 \%$ aqueous $\mathrm{H}_{3} \mathrm{PO}_{4}$, and extracted with $\mathrm{CHCl}_{3}(4 \times 20 \mathrm{ml})$. The organic layers were combined, dried over $\mathrm{MgSO}_{4}$, and concentrated in vacuo. The oily residue was dissolved in a mixture of $\mathrm{MeOH}(1 \mathrm{ml})$ and benzene $(4 \mathrm{ml})$, and $2.0 \mathrm{M} \mathrm{Me}_{3} \mathrm{SiCHN}_{2}$ solution in hexane $(0.3 \mathrm{ml})$ was added. The resulting solution was concentrated in vacuo, and the residue was purified by flash chromatography [AcOEt-EtOH $(10: 1, \mathrm{v} / \mathrm{v})]$ to give $\mathbf{1 0}(115 \mathrm{mg}, 23 \%)$ as a yellow glass. The diastereomeric mixture thus obtained was dissolved in $\mathrm{Me}_{2} \mathrm{CO}(15 \mathrm{ml})$. After a solution of $\mathrm{N}$-methylmorpholine $\mathrm{N}$-oxide monohydrate $(42 \mathrm{mg}, 0.31 \mathrm{mmol})$ in $0.5 \mathrm{M}$ phosphate buffer $(\mathrm{pH} 6,15 \mathrm{ml})$ and a $1.6 \%$ $(\mathrm{w} / \mathrm{v}) \mathrm{OsO}_{4}$ solution in $\mathrm{Me}_{3} \mathrm{COH}(0.4 \mathrm{ml})$ were added, the mixture was stirred at room temperature for $5 \mathrm{~h}$ and then for a further $30 \mathrm{~min}$ after the addition of $\mathrm{Na}_{2} \mathrm{~S}_{2} \mathrm{O}_{5}(57 \mathrm{mg}, 0.30 \mathrm{mmol})$. The resulting suspension was concentrated to half the initial volume and extracted with $\mathrm{CHCl}_{3}(2 \times 20 \mathrm{ml})$. The organic layers were combined, washed with saturated aqueous $\mathrm{NaCl}$, dried over $\mathrm{MgSO}_{4}$, and concentrated in vacuo to leave a colorless glass (109 $\mathrm{mg})$. This was purified by flash chromatography $\left[\mathrm{CHCl}_{3}-\mathrm{MeOH}(10: 1, \mathrm{v} / \mathrm{v})\right]$, providing a colorless glass $(57 \mathrm{mg})$. A portion $(20 \mathrm{mg})$ of this mixture of the diols was treated with triphosgene $(18 \mathrm{mg})$ in $\mathrm{CH}_{2} \mathrm{Cl}_{2}(2 \mathrm{ml})$ in the presence of pyridine $(0.03 \mathrm{ml})$ at $0{ }^{\circ} \mathrm{C}$ for $20 \mathrm{~min}$. The resulting solution was washed successively with $\mathrm{H}_{2} \mathrm{O}(3 \mathrm{ml}), 5 \%$ aqueous citric acid $(2 \times 3 \mathrm{ml})$, and $\mathrm{H}_{2} \mathrm{O}$ $(2 \times 3 \mathrm{ml})$, dried over $\mathrm{MgSO}_{4}$, and concentrated in vacuo, leaving a colorless glass $(7 \mathrm{mg})$. A portion $(5 \mathrm{mg})$ of this material was hydrogenated over Pearlman's catalyst $(15 \mathrm{mg})$ in $\mathrm{MeOH}(4 \mathrm{ml})$ at $40^{\circ} \mathrm{C}$ for $2 \mathrm{~h}$. The catalyst was removed by filtration and washed with hot $\mathrm{MeOH}(50 \mathrm{ml})$. The filtrate and washings were combined and concentrated in vacuo. The residue was purified by TLC on silica gel $\left[\mathrm{CHCl}_{3}-\mathrm{MeOH}(10: 1, \mathrm{v} / \mathrm{v})\right]$ to give a diastereomeric mixture of the monohydroxy compounds $(2 \mathrm{mg})$ as a colorless glass. After a solution of this product in $0.1 \mathrm{M} \mathrm{MeONa}-\mathrm{MeOH}(0.15 \mathrm{ml})$ was stored at $0{ }^{\circ} \mathrm{C}$ for $5 \mathrm{~min}, 0.1 \mathrm{M}$ aqueous $\mathrm{NaH}_{2} \mathrm{PO}_{4}(0.3 \mathrm{ml})$ was added at once. The resulting mixture was concentrated in vacuo, and the residue was purified by TLC on silica gel $\left[\mathrm{CHCl}_{3}-\mathrm{MeOH}(5: 1, \mathrm{v} / \mathrm{v})\right]$, giving a colorless glass $(1 \mathrm{mg})$. Separation of the diastereomers thus obtained was accomplished by HPLC [LiChrosorb RP18 ( $7 \mu \mathrm{m}, 250 \times 10 \mathrm{~mm})$ (Merck); MeOH$\mathrm{H}_{2} \mathrm{O}(30: 70, \mathrm{v} / \mathrm{v})$ at the rate of $\left.5 \mathrm{ml} / \mathrm{min}\right]$ in two portions. The molar ratio of the diastereomers was $1: 2: 2: 1$ in the order of elution. The isomer that was eluted the fastest was identical (by comparison of the ${ }^{1} \mathrm{H}-\mathrm{NMR}$ spectrum and HPLC mobility) to the authentic $(\alpha S, \beta S)-11$ described below. $(\alpha R, \beta S)$ $\beta$-Hydroxy- $\alpha$-[(methoxycarbonyl)amino]-4,6-dimethyl-9-oxo-3- $\beta$-D-ribofuranosyl-4,9-dihydro-3H-imidazo[1,2-a]purine-7-butanoic acid methyl ester $[(\alpha R, \beta S)-11]$ was obtained from the second fraction, ${ }^{1} \mathrm{H}-\mathrm{NMR}\left[\left(\mathrm{CD}_{3}\right)_{2} \mathrm{CO}\right]$ $\delta^{24)}: 2.19[3 \mathrm{H}, \mathrm{s}, \mathrm{C}(6)-\mathrm{Me}], 3.28(\mathrm{dd}, J=14.2,5.5 \mathrm{~Hz}), 3.36(\mathrm{dd}, J=14.2$, $7 \mathrm{~Hz}$ ) [1 $\mathrm{H}$ each, $\left.\mathrm{C}(\gamma)-\mathrm{H}_{2}\right], 3.68,3.69$ ( $3 \mathrm{H}$ each, s, $\mathrm{CCO}_{2} \mathrm{Me}$ and $\left.\mathrm{NCO}_{2} \mathrm{Me}\right)$, 3.85 (ddd, $J=12.2,5.4,2.9 \mathrm{~Hz}), 3.94(\mathrm{ddd}, J=12.2,4.9,2.9 \mathrm{~Hz})[1 \mathrm{H}$ each, $\left.\mathrm{C}\left(5^{\prime}\right)-\mathrm{H}_{2}\right], 4.21\left[1 \mathrm{H}, \mathrm{m}, \mathrm{C}\left(4^{\prime}\right)-\mathrm{H}\right], 4.22(3 \mathrm{H}, \mathrm{s}, \mathrm{NMe}), 4.26[1 \mathrm{H}, \mathrm{dd}, J=1.5$, $9.3 \mathrm{~Hz}, \mathrm{C}(\alpha)-\mathrm{H}], 4.49\left[2 \mathrm{H}, \mathrm{m}, \mathrm{C}\left(5^{\prime}\right)-\mathrm{OH}, \mathrm{C}\left(3^{\prime}\right)-\mathrm{H}\right], 4.57-4.67[2 \mathrm{H}, \mathrm{m}$, $\mathrm{C}(\beta)-\mathrm{OH}, \mathrm{C}(\beta)-\mathrm{H}], 4.74\left[1 \mathrm{H}, \mathrm{m}, \mathrm{C}\left(2^{\prime}\right)-\mathrm{H}\right], 4.78\left[1 \mathrm{H}, \mathrm{br}, \mathrm{C}\left(3^{\prime}\right)-\mathrm{OH}\right], 5.13$ $\left[1 \mathrm{H}, \mathrm{br}, \mathrm{C}\left(2^{\prime}\right)-\mathrm{OH}\right], 6.19[1 \mathrm{H}, \mathrm{d}, J=9.3 \mathrm{~Hz}, \mathrm{C}(\alpha)-\mathrm{NH}], 6.30[1 \mathrm{H}, \mathrm{d}, J=4.9$ $\left.\mathrm{Hz}, \mathrm{C}\left(1^{\prime}\right)-\mathrm{H}\right], 8.21[1 \mathrm{H}, \mathrm{s}, \mathrm{C}(2)-\mathrm{H}]$. The isomer obtained from the third frac- tion was identical (by comparison of the ${ }^{1} \mathrm{H}-\mathrm{NMR}$ spectrum and HPLC mobility) with authentic $(\alpha S, \beta R)$-11 described below. $(\alpha R, \beta R)-\beta$-Hydroxy- $\alpha$ [(methoxycarbonyl)amino]-4,6-dimethyl-9-oxo-3- $\beta$-D-ribofuranosyl-4,9-dihydro-3H-imidazo[1,2-a]purine-7-butanoic acid methyl ester $[(\alpha R, \beta R)-11]$ was obtained from the fourth fraction, ${ }^{1} \mathrm{H}-\mathrm{NMR}\left[\left(\mathrm{CD}_{3}\right)_{2} \mathrm{CO}\right] \delta^{24)}: 2.24[3 \mathrm{H}$, s, C(6)-Me], $3.18\left[1 \mathrm{H}\right.$, dd, $J=14.7,8.3 \mathrm{~Hz}$, one $\left.\mathrm{C}(\gamma)-\mathrm{H}_{2}\right], 3.64,3.67[3 \mathrm{H}$ each, s, overlapping with a $1 \mathrm{H}$ signal arising from one $\mathrm{C}(\gamma)-\mathrm{H}_{2}, \mathrm{CCO}_{2} \mathrm{Me}$ and $\mathrm{NCO}_{2} \mathrm{Me}$ ], 3.84, 3.92 [1H each, $\left.\mathrm{m}, \mathrm{C}\left(5^{\prime}\right)-\mathrm{H}_{2}\right], 4.21\left[1 \mathrm{H}, \mathrm{m}, \mathrm{C}\left(4^{\prime}\right)-\mathrm{H}\right]$, $4.24(3 \mathrm{H}, \mathrm{s}, \mathrm{NMe}), 4.28[1 \mathrm{H}, \mathrm{m}, \mathrm{C}(\beta)-\mathrm{H}], 4.37[1 \mathrm{H}, \mathrm{m}, \mathrm{C}(\alpha)-\mathrm{H}], 4.49[2 \mathrm{H}$, $\mathrm{m}, \mathrm{C}\left(5^{\prime}\right)-\mathrm{OH}$ and $\left.\mathrm{C}\left(3^{\prime}\right)-\mathrm{H}\right], 4.58[1 \mathrm{H}, \mathrm{br}, \mathrm{C}(\beta)-\mathrm{OH}], 4.74\left[1 \mathrm{H}, \mathrm{m}, \mathrm{C}\left(2^{\prime}\right)-\mathrm{H}\right]$, $4.90\left[1 \mathrm{H}, \mathrm{br}, \mathrm{C}\left(3^{\prime}\right)-\mathrm{OH}\right], 5.25\left[1 \mathrm{H}, \mathrm{br}, \mathrm{C}\left(2^{\prime}\right)-\mathrm{OH}\right], 6.30[1 \mathrm{H}, \mathrm{d}, J=4.9 \mathrm{~Hz}$, $\left.\mathrm{C}\left(1^{\prime}\right)-\mathrm{H}\right], 6.68$ [1H, d, $\left.J=7.8 \mathrm{~Hz}, \mathrm{C}(\alpha)-\mathrm{NH}\right], 8.21[1 \mathrm{H}, \mathrm{s}, \mathrm{C}(2)-\mathrm{H}]$.

Dihydroxylation of $13 \mathrm{~A}$ solution of $\mathrm{N}$-methylmorpholine $\mathrm{N}$-oxide monohydrate $(90 \mathrm{mg}, 0.67 \mathrm{mmol})$ in $0.5 \mathrm{M}$ phosphate buffer $(\mathrm{pH} 6,33 \mathrm{ml})$ and a $1.1 \%(\mathrm{w} / \mathrm{v}) \mathrm{OsO}_{4}$ solution in $\mathrm{Me}_{3} \mathrm{COH}(1.2 \mathrm{ml}, 0.05 \mathrm{mmol})$ were added to a solution of $\mathbf{1 3}^{2)}(333 \mathrm{mg}, 0.392 \mathrm{mmol})$ in $\mathrm{Me}_{2} \mathrm{CO}(33 \mathrm{ml})$. The resulting mixture was stirred at room temperature for $4 \mathrm{~h}$ and then for a further $30 \mathrm{~min}$ after the addition of $\mathrm{Na}_{2} \mathrm{~S}_{2} \mathrm{O}_{5}$ (124 mg, $\left.0.652 \mathrm{mmol}\right)$. The mixture was concentrated to half the initial volume and extracted with $\mathrm{CH}_{2} \mathrm{Cl}_{2}(3 \times 20 \mathrm{ml})$. The organic layers were combined, dried over $\mathrm{MgSO}_{4}$, and concentrated in vacuo to leave a foam $(341 \mathrm{mg})$. This was dissolved in hexane $(4 \mathrm{ml})$ and the solution was subjected to HPLC [LiChrosorb Si-60 $(7 \mu \mathrm{m}, 250 \times 10 \mathrm{~mm})$ (Merck); hexane- $\left.\mathrm{CHCl}_{3}-\mathrm{MeOH}(50: 48: 2, \mathrm{v} / \mathrm{v})\right]$ in eight portions, providing $(\alpha S, \beta S, \gamma S)-\beta, \gamma$-dihydroxy- $\alpha$-[(methoxycarbonyl)amino]-4,6-dimethyl9-oxo-3-[2,3,5-tris- $O$-(tert-butyldimethylsilyl)- $\beta$-D-ribofuranosyl]-4,9-dihydro-3H-imidazo[1,2- $a]$ purine-7-butanoic acid methyl ester monohydrate $\left(\mathbf{1 4} \cdot \mathrm{H}_{2} \mathrm{O}\right)(176 \mathrm{mg}, 50 \%), \mathrm{mp} 117-121^{\circ} \mathrm{C}$. Recrystallization of this sample from $90 \%(\mathrm{v} / \mathrm{v})$ aqueous $\mathrm{MeOH}$ and drying over $\mathrm{P}_{2} \mathrm{O}_{5}$ at $2 \mathrm{mmHg}$ and $50{ }^{\circ} \mathrm{C}$ for $17 \mathrm{~h}$ afforded an analytical sample of $\mathbf{1 4} \cdot \mathrm{H}_{2} \mathrm{O}$ as colorless needles, mp $115^{\circ} \mathrm{C}$ (softened) $207-209.5^{\circ} \mathrm{C} .[\alpha]_{\mathrm{D}}^{20}-14.2^{\circ}(c=0.456, \mathrm{MeOH})$. FABMS $m / z: 905\left(\mathrm{MNa}^{+}\right), 865\left(\mathrm{MH}^{+}-18\right)$. UV $\lambda_{\max }^{95 \% \mathrm{EtOH}} \mathrm{nm}(\varepsilon): 240$ (35600), 297 (7000). IR $v_{\max }^{\text {Nujol }} \mathrm{cm}^{-1}: 1746,1725,1684(\mathrm{C}=\mathrm{O}) .{ }^{1} \mathrm{H}-\mathrm{NMR}\left(\mathrm{CDCl}_{3}\right) \delta$ : $-0.29,-0.02,0.13,0.15,0.16,0.17$ (3H each, s, three $\mathrm{SiMe}_{2}$ ), 0.75, 0.95, $0.97\left(9 \mathrm{H}\right.$ each, s, three tert-Bu), $1.56\left(\mathrm{~s}, \mathrm{H}_{2} \mathrm{O}\right), 2.24[3 \mathrm{H}, \mathrm{s}, \mathrm{C}(6)-\mathrm{Me}], 3.44$ $[1 \mathrm{H}$, br s, $\mathrm{C}(\beta)-\mathrm{OH}], 3.66,3.72\left(3 \mathrm{H}\right.$ each, $\mathrm{s}, \mathrm{CCO}_{2} \mathrm{Me}$ and $\left.\mathrm{NCO}_{2} \mathrm{Me}\right), 3.80$ $\left[1 \mathrm{H}, \mathrm{dd}, J=11.7,1.5 \mathrm{~Hz}\right.$, one $\left.\mathrm{C}\left(5^{\prime}\right)-\mathrm{H}_{2}\right], 3.88[1 \mathrm{H}, \mathrm{d}, J=10 \mathrm{~Hz}, \mathrm{C}(\alpha)-\mathrm{H}]$, $3.89\left[1 \mathrm{H}, \mathrm{dd}, J=11.7,2.5 \mathrm{~Hz}\right.$, one $\left.\mathrm{C}\left(5^{\prime}\right)-\mathrm{H}_{2}\right], 4.13[1 \mathrm{H}, \mathrm{dd}, J=1.5,2.5 \mathrm{~Hz}$, $\left.\mathrm{C}\left(4^{\prime}\right)-\mathrm{H}\right], 4.18(3 \mathrm{H}, \mathrm{s}, \mathrm{NMe}), 4.20\left[1 \mathrm{H}, \mathrm{d}, J=4.4 \mathrm{~Hz}, \mathrm{C}\left(3^{\prime}\right)-\mathrm{H}\right], 4.42[1 \mathrm{H}, \mathrm{dd}$, $\left.J=4.4,7.8 \mathrm{~Hz}, \mathrm{C}\left(2^{\prime}\right)-\mathrm{H}\right], 4.53(0.1 \mathrm{H}), 4.57(0.9 \mathrm{H})$ [d each, $J=9.8 \mathrm{~Hz}, \mathrm{C}(\beta)-$ $\mathrm{H}], 4.79[1 \mathrm{H}, \mathrm{dd}, J=9.8,11.7 \mathrm{~Hz}, \mathrm{C}(\gamma)-\mathrm{H}], 5.46(0.1 \mathrm{H}), 5.61(0.9 \mathrm{H})[\mathrm{d}$ each, $J=10 \mathrm{~Hz}, \mathrm{C}(\alpha)-\mathrm{NH}], 5.62[1 \mathrm{H}, \mathrm{d}, J=11.7 \mathrm{~Hz}, \mathrm{C}(\gamma)-\mathrm{OH}], 6.25[1 \mathrm{H}, \mathrm{d}, J=7.8$ $\left.\mathrm{Hz}, \mathrm{C}\left(1^{\prime}\right)-\mathrm{H}\right], 8.04$ [1H, s, C(2)-H]. Anal. Calcd for $\mathrm{C}_{30} \mathrm{H}_{70} \mathrm{~N}_{6} \mathrm{O}_{11} \mathrm{Si}_{3} \cdot \mathrm{H}_{2} \mathrm{O}: \mathrm{C}$, $51.97 ; \mathrm{H}, 8.05 ; \mathrm{N}, 9.32$. Found: C, 52.12; H, 7.94; N, 9.38. $(\alpha S, \beta R, \gamma R)-\beta, \gamma-$ Dihydroxy- $\alpha$-[(methoxycarbonyl)amino]-4,6-dimethyl-9-oxo-3-[2,3,5-tris$O$-(tert-butyldimethylsilyl)- $\beta$-D-ribofuranosyl]-4,9-dihydro-3H-imidazo[1,2a]purine-7-butanoic acid methyl ester (16) $(103 \mathrm{mg}, 30 \%)$ was obtained from a later fraction as a colorless glass, $[\alpha]_{\mathrm{D}}^{26}-13.9^{\circ}(c=0.512, \mathrm{MeOH})$. FAB-MS $m / z$ : $905\left(\mathrm{MNa}^{+}\right), 865\left(\mathrm{MH}^{+}-18\right) .{ }^{1} \mathrm{H}-\mathrm{NMR}\left(\mathrm{CDCl}_{3}\right) \delta:-0.23$, $-0.01,0.13,0.14$ (3H each), $0.15(6 \mathrm{H})\left(\mathrm{s}\right.$, three $\left.\mathrm{SiMe}_{2}\right), 0.75,0.949,0.953$ $(9 \mathrm{H}$ each, $\mathrm{s}$, three tert-Bu), $2.39[3 \mathrm{H}, \mathrm{s}, \mathrm{C}(6)-\mathrm{Me}], 3.51[1 \mathrm{H}, \mathrm{br}, \mathrm{C}(\beta)-\mathrm{OH}]$, $3.55,3.77\left(3 \mathrm{H}\right.$ each, $\mathrm{s}, \mathrm{NCO}_{2} \mathrm{Me}$ and $\left.\mathrm{CCO}_{2} \mathrm{Me}\right), 3.79(\mathrm{dd}, J=11.5,1.5 \mathrm{~Hz})$, $3.88(\mathrm{dd}, J=11.7,2.5 \mathrm{~Hz})\left[1 \mathrm{H}\right.$ each, $\left.\mathrm{C}\left(5^{\prime}\right)-\mathrm{H}_{2}\right], 4.13[1 \mathrm{H}, \mathrm{dd}, J=1.5,2.5 \mathrm{~Hz}$, $\left.\mathrm{C}\left(4^{\prime}\right)-\mathrm{H}\right], 4.17(3 \mathrm{H}, \mathrm{s}, \mathrm{NMe}), 4.21\left[1 \mathrm{H}, \mathrm{d}, J=4.4 \mathrm{~Hz}, \mathrm{C}\left(3^{\prime}\right)-\mathrm{H}\right], 4.22[1 \mathrm{H}, \mathrm{m}$, $\mathrm{C}(\alpha)-\mathrm{H}], 4.30[1 \mathrm{H}, \mathrm{dd}, J=2.4,8.3 \mathrm{~Hz}, \mathrm{C}(\beta)-\mathrm{H}], 4.44[1 \mathrm{H}, \mathrm{dd}, J=4.4,7.3 \mathrm{~Hz}$, $\left.\mathrm{C}\left(2^{\prime}\right)-\mathrm{H}\right], 5.16[1 \mathrm{H}, \mathrm{dd}, J=8.3,11.2 \mathrm{~Hz}, \mathrm{C}(\gamma)-\mathrm{H}], 5.45[1 \mathrm{H}, \mathrm{d}, J=11.2 \mathrm{~Hz}$, $\mathrm{C}(\gamma)-\mathrm{OH}], 5.62(0.1 \mathrm{H}, \mathrm{d}, J=10 \mathrm{~Hz}), 5.72(0.9 \mathrm{H}, \mathrm{d}, J=7.8 \mathrm{~Hz})[\mathrm{C}(\alpha)-\mathrm{NH}]$, $6.22\left[1 \mathrm{H}, \mathrm{d}, J=7.3 \mathrm{~Hz}, \mathrm{C}\left(1^{\prime}\right)-\mathrm{H}\right], 8.00[1 \mathrm{H}, \mathrm{s}, \mathrm{C}(2)-\mathrm{H}]$

$(\alpha S, 4 S, 5 S)$-5-[4,6-Dimethyl-9-oxo-3-[2,3,5-tris-O-(tert-butyldimethylsilyl)- $\beta$-D-ribofuranosyl]-4,9-dihydro-3H-imidazo[1,2-a]purin-7-yl]- $\alpha$ [(methoxycarbonyl)amino]-2-oxo-1,3-dioxolane-4-acetic Acid Methyl Ester (15) A solution of $\mathbf{1 4} \cdot \mathrm{H}_{2} \mathrm{O}(65 \mathrm{mg}, 0.072 \mathrm{mmol})$ in benzene $(5 \mathrm{ml})$ was dried over $\mathrm{MgSO}_{4}$ and concentrated in vacuo. The residual foam was dried over $\mathrm{P}_{2} \mathrm{O}_{5}$ at $2 \mathrm{mmHg}$ at room temperature for $3 \mathrm{~h}$. This was dissolved in $\mathrm{CH}_{2} \mathrm{Cl}_{2}(2 \mathrm{ml})$, and pyridine $(0.06 \mathrm{ml}, 0.7 \mathrm{mmol})$ was added. A solution of triphosgene $(16 \mathrm{mg}, 0.054 \mathrm{mmol})$ in $\mathrm{CH}_{2} \mathrm{Cl}_{2}(2 \mathrm{ml})$ was then added dropwise at $0{ }^{\circ} \mathrm{C}$ over a period of $3 \mathrm{~min}$, and the mixture was stirred at $0{ }^{\circ} \mathrm{C}$ for a further $15 \mathrm{~min}$. The reaction mixture was diluted with $\mathrm{CH}_{2} \mathrm{Cl}_{2}(5 \mathrm{ml})$, washed successively with $\mathrm{H}_{2} \mathrm{O}(5 \mathrm{ml}), 5 \%$ aqueous citric acid $(2 \times 5 \mathrm{ml})$, and saturated aqueous $\mathrm{NaHCO}_{3}(5 \mathrm{ml})$, dried over $\mathrm{MgSO}_{4}$, and concentrated in vacuo, leaving a yellow glass. This was purified by flash chromatography [hexane-AcOEt $(2: 3, \mathrm{v} / \mathrm{v})]$ to give $\mathbf{1 5}(53 \mathrm{mg}, 80 \%)$ as a faintly yellow glass, $[\alpha]_{\mathrm{D}}^{18}-50.6^{\circ}(c=0.425, \mathrm{MeOH})$. FAB-MS $m / z$ : $909\left(\mathrm{MH}^{+}\right) .{ }^{1} \mathrm{H}-\mathrm{NMR}$ $\left(\mathrm{CDCl}_{3}\right) \delta:-0.27,-0.02,0.13(3 \mathrm{H}$ each $), 0.15(6 \mathrm{H}), 0.16(3 \mathrm{H}),(\mathrm{s}$, three $\mathrm{SiMe}_{2}$ ), 0.76, 0.95, 0.96 (9H each, s, three tert-Bu), 2.38 [3H, s, C(6)-Me], 
3.78, 3.79 ( $3 \mathrm{H}$ each, s, two $\mathrm{CO}_{2} \mathrm{Me}$ ), 3.79 (dd, $J=11.7,2 \mathrm{~Hz}$ ), 3.87 (dd, $J=11.7,2.9 \mathrm{~Hz})\left[1 \mathrm{H}\right.$ each, $\left.\mathrm{C}\left(5^{\prime}\right)-\mathrm{H}_{2}\right], 4.12\left[1 \mathrm{H}, \mathrm{dd}, J=2,2.9 \mathrm{~Hz}, \mathrm{C}\left(4^{\prime}\right)-\mathrm{H}\right]$, $4.14(3 \mathrm{H}, \mathrm{s}, \mathrm{NMe}), 4.20\left[1 \mathrm{H}, \mathrm{d}, J=4 \mathrm{~Hz}, \mathrm{C}\left(3^{\prime}\right)-\mathrm{H}\right], 4.42[1 \mathrm{H}, \mathrm{dd}, J=4,7.5$ $\left.\mathrm{Hz}, \mathrm{C}\left(2^{\prime}\right)-\mathrm{H}\right], 4.67[1 \mathrm{H}, \mathrm{dd}, J=1,9 \mathrm{~Hz}, \mathrm{C}(\alpha)-\mathrm{H}], 5.41[1 \mathrm{H}, \mathrm{dd}, J=1,7.3 \mathrm{~Hz}$, $\mathrm{C}(\beta)-\mathrm{H}], 5.62[1 \mathrm{H}, \mathrm{d}, J=9 \mathrm{~Hz}, \mathrm{C}(\alpha)-\mathrm{NH}], 5.83[1 \mathrm{H}, \mathrm{d}, J=7.3 \mathrm{~Hz}, \mathrm{C}(\gamma)-\mathrm{H}]$, $6.23\left[1 \mathrm{H}, \mathrm{d}, J=7.5 \mathrm{~Hz}, \mathrm{C}\left(1^{\prime}\right)-\mathrm{H}\right], 8.00[1 \mathrm{H}, \mathrm{s}, \mathrm{C}(2)-\mathrm{H}]$.

$(\alpha S, 4 R, 5 R)-5$-[4,6-Dimethyl-9-0xo-3-[2,3,5-tris-O-(tert-butyldimethylsilyl)- $\beta$-D-ribofuranosyl]-4,9-dihydro-3H-imidazo[1,2-a]purin-7-yl]- $\alpha$ [(methoxycarbonyl)amino]-2-oxo-1,3-dioxolane-4-acetic Acid Methyl Ester (26) A solution of triphosgene $(6 \mathrm{mg}, 0.02 \mathrm{mmol})$ in dry $\mathrm{CH}_{2} \mathrm{Cl}_{2}(0.6$ $\mathrm{ml})$ was added dropwise to a solution of $\mathbf{1 6}(7.8 \mathrm{mg}, 0.0088 \mathrm{mmol}), \mathbf{5}^{3,16}$ $(9.0 \mathrm{mg}, 0.018 \mathrm{mmol})$, and pyridine $(0.03 \mathrm{ml})$ in $\mathrm{CH}_{2} \mathrm{Cl}_{2}(0.6 \mathrm{ml})$ at $0{ }^{\circ} \mathrm{C}$ under $\mathrm{N}_{2}$ over a period of $3 \mathrm{~min}$, and the mixture was stirred at $0^{\circ} \mathrm{C}$ for a further $15 \mathrm{~min}$. The reaction mixture was diluted with $\mathrm{CH}_{2} \mathrm{Cl}_{2}(5 \mathrm{ml})$, washed successively with $\mathrm{H}_{2} \mathrm{O}, 5 \%$ aqueous citric acid, and saturated aqueous $\mathrm{NaHCO}_{3}\left(5 \mathrm{ml}\right.$ each), dried over $\mathrm{MgSO}_{4}$, and concentrated in vacuo, leaving a yellow glass. This was purified by column chromatography on silica gel (AcOEt) to give $\mathbf{2 6}(4.6 \mathrm{mg}, 57 \%)$ as a faintly yellow glass, ${ }^{1} \mathrm{H}-\mathrm{NMR}$ $\left(\mathrm{CDCl}_{3}\right) \delta:-0.26,-0.01,0.13(3 \mathrm{H} \mathrm{each}), 0.14(6 \mathrm{H}), 0.15(3 \mathrm{H})$, (s, three $\left.\mathrm{SiMe}_{2}\right), 0.76,0.947,0.953$ (9H each, s, three tert-Bu), $2.36[3 \mathrm{H}, \mathrm{s}, \mathrm{C}(6)-$ $\mathrm{Me}$, 3.69, 3.77 ( $3 \mathrm{H}$ each, s, $\mathrm{CCO}_{2} \mathrm{Me}$ and $\mathrm{NCO}_{2} \mathrm{Me}$ ), 3.79 (dd, $J=11.7,2$ $\mathrm{Hz}$ ), $3.88\left(\mathrm{dd}, J=11.7,2.9 \mathrm{~Hz}\right.$ ) [1H each, $\left.\mathrm{C}\left(5^{\prime}\right)-\mathrm{H}_{2}\right], 4.12$ [1H, dd, $J=2,2.9$ $\left.\mathrm{Hz}, \mathrm{C}\left(4^{\prime}\right)-\mathrm{H}\right], 4.13(3 \mathrm{H}, \mathrm{s}, \mathrm{NMe}), 4.20\left[1 \mathrm{H}, \mathrm{d}, J=4.4 \mathrm{~Hz}, \mathrm{C}\left(3^{\prime}\right)-\mathrm{H}\right], 4.41$ $\left[1 \mathrm{H}, \mathrm{dd}, J=4.4,7.8 \mathrm{~Hz}, \mathrm{C}\left(2^{\prime}\right)-\mathrm{H}\right], 4.86[1 \mathrm{H}, \mathrm{dd}, J=3.4,8.8 \mathrm{~Hz}, \mathrm{C}(\alpha)-\mathrm{H}]$, $5.20[1 \mathrm{H}, \mathrm{dd}, J=3.4,7.3 \mathrm{~Hz}, \mathrm{C}(\beta)-\mathrm{H}], 5.69$ [a total of $1 \mathrm{H}$ with a small broad signal at $5.35, \mathrm{br}, \mathrm{C}(\alpha)-\mathrm{NH}], 6.21\left[1 \mathrm{H}, \mathrm{d}, J=7.8 \mathrm{~Hz}, \mathrm{C}\left(1^{\prime}\right)-\mathrm{H}\right], 6.43[1 \mathrm{H}, \mathrm{d}$, $J=7.3 \mathrm{~Hz}, \mathrm{C}(\gamma)-\mathrm{H}], 7.98[1 \mathrm{H}, \mathrm{s}, \mathrm{C}(2)-\mathrm{H}]$. Compound $\mathbf{6}^{3,16)}(5.9 \mathrm{mg}, 62 \%)$ was obtained from the later fraction.

$(\alpha S, \beta R)-\beta$-Hydroxy- $\alpha$-[(methoxycarbonyl)amino]-4,6-dimethyl-9-oxo3-[2,3,5-tris- $O$-(tert-butyldimethylsilyl)- $\beta$-D-ribofuranosyl]-4,9-dihydro3H-imidazo[1,2-a]purine-7-butanoic Acid Methyl Ester (17) Compound $15(52 \mathrm{mg}, 0.057 \mathrm{mmol})$ was hydrogenated over Pearlman's catalyst $(52 \mathrm{mg})$ in $\mathrm{MeOH}(20 \mathrm{ml})$ at $40^{\circ} \mathrm{C}$ under atmospheric pressure for $3 \mathrm{~h}$. The catalyst was filtered off and washed with hot $\mathrm{MeOH}(100 \mathrm{ml})$. The filtrate and washings were combined and concentrated in vacuo to leave a colorless glass. This was purified by TLC on silica gel $\left[\mathrm{CHCl}_{3}-\mathrm{MeOH}(40: 1, \mathrm{v} / \mathrm{v})\right]$ to give $\mathbf{1 8}^{2)}(11.2 \mathrm{mg}, 23 \%)$ and $\mathbf{1 7}(14.3 \mathrm{mg}, 29 \%)$ as a colorless glass, $[\alpha]_{D}^{18}$ $-28.6^{\circ}(c=0.500, \mathrm{MeOH})$. FAB-MS $m / z: 889\left(\mathrm{MNa}^{+}\right), 867\left(\mathrm{MH}^{+}\right) .{ }^{1} \mathrm{H}-$ $\operatorname{NMR}\left(\mathrm{CDCl}_{3}\right) \delta:-0.28,-0.03,0.12(3 \mathrm{H}$ each $), 0.14(6 \mathrm{H}), 0.15(3 \mathrm{H})(\mathrm{s}$, three $\left.\mathrm{SiMe}_{2}\right), 0.74,0.94,0.95$ (9H each, s, three tert-Bu), $2.25[3 \mathrm{H}, \mathrm{s}, \mathrm{C}(6)-$ Me], 3.15 (dd, $J=15,3.5 \mathrm{~Hz}$ ), 3.57 (dd, $J=15,8.5 \mathrm{~Hz})$ [1H each, $\mathrm{C}(\gamma)-\mathrm{H}_{2}$ ], $3.72,3.76\left(3 \mathrm{H}\right.$ each, s, two $\mathrm{CO}_{2} \mathrm{Me}$ ), 3.79 (dd, $J=11.7,1.5 \mathrm{~Hz}$ ), 3.87 (dd, $J=11.7,2.9 \mathrm{~Hz})\left[1 \mathrm{H}\right.$ each, $\left.\mathrm{C}\left(5^{\prime}\right)-\mathrm{H}_{2}\right], 4.11[3 \mathrm{H}$, s, overlapping with a $1 \mathrm{H}$ signal arising from $\left.\mathrm{C}\left(4^{\prime}\right)-\mathrm{H}, \mathrm{NMe}\right], 4.17[1 \mathrm{H}, \mathrm{d}, J=5.4 \mathrm{~Hz}, \mathrm{C}(\beta)-\mathrm{OH}], 4.19$ $\left[1 \mathrm{H}, \mathrm{d}, J=4.4 \mathrm{~Hz}, \mathrm{C}\left(3^{\prime}\right)-\mathrm{H}\right], 4.39[1 \mathrm{H}, \mathrm{dd}, J=4.4,7.5 \mathrm{~Hz}$, overlapping with a $1 \mathrm{H}$ signal arising from $\left.\mathrm{C}(\beta)-\mathrm{H}, \mathrm{C}\left(2^{\prime}\right)-\mathrm{H}\right], 4.46[1 \mathrm{H}, \mathrm{d}, J=9 \mathrm{~Hz}, \mathrm{C}(\alpha)-\mathrm{H}]$, $5.66[1 \mathrm{H}, \mathrm{d}, J=9 \mathrm{~Hz}, \mathrm{C}(\alpha)-\mathrm{NH}], 6.21\left[1 \mathrm{H}, \mathrm{d}, J=7.5 \mathrm{~Hz}, \mathrm{C}\left(1^{\prime}\right)-\mathrm{H}\right], 7.94[1 \mathrm{H}$, $\mathrm{s}, \mathrm{C}(2)-\mathrm{H}]$.

$(\alpha S, \beta S)-\beta$-Hydroxy- $\alpha-[($ methoxycarbonyl)amino]-4,6-dimethyl-9-oxo3-[2,3,5-tris- $O$-(tert-butyldimethylsilyl)- $\beta$-D-ribofuranosyl]-4,9-dihydro3H-imidazo[1,2-a]purine-7-butanoic Acid Methyl Ester (27) i) Dihydroxylation of $\mathbf{1 3}^{2)}(300 \mathrm{mg}, 0.353 \mathrm{mmol})$ was conducted in a manner similar to that described above, and the crude product was purified by flash chromatography $\left[\mathrm{CHCl}_{3}-\mathrm{MeOH}(30: 1, \mathrm{v} / \mathrm{v})\right]$ to give a $2.1: 1$ (estimated by ${ }^{1} \mathrm{H}-$ NMR spectroscopy) mixture $(288 \mathrm{mg})$ of $\mathbf{1 4}$ and 16. A portion $(277 \mathrm{mg}$, $0.314 \mathrm{mmol})$ of this product was treated with triphosgene $(70 \mathrm{mg}, 0.24$ $\mathrm{mmol}$ ) in a manner similar to that described above for the preparation of $\mathbf{1 5}$. The crude product was purified by flash chromatography [hexane-AcOEt $(2: 3, \mathrm{v} / \mathrm{v})]$ to give a $2.9: 1$ (estimated by ${ }^{1} \mathrm{H}$-NMR spectroscopy) mixture $(195 \mathrm{mg})$ of 15 and 26. The mixture $(194 \mathrm{mg})$ was shaken in $\mathrm{MeOH}(77 \mathrm{ml})$ under $\mathrm{H}_{2}$ in the presence of Pearlman's catalyst $(194 \mathrm{mg})$ at $40^{\circ} \mathrm{C}$ for $2 \mathrm{~h}$. The catalyst was filtered off and washed with hot $\mathrm{MeOH}(100 \mathrm{ml})$. The filtrate and washings were combined and concentrated in vacuo. The residue was purified by repeated flash chromatography and TLC on silica gel $\left[\mathrm{CHCl}_{3}-\mathrm{MeOH}(40: 1, \mathrm{v} / \mathrm{v})\right]$, providing $\mathbf{1 8}^{2)}(79 \mathrm{mg}, 28 \%), 17(61 \mathrm{mg}, 21 \%)$, and $27(23 \mathrm{mg}, 8 \%)$ as a colorless glass, $[\alpha]_{\mathrm{D}}^{18}-21.5^{\circ}(c=0.413, \mathrm{MeOH})$. FAB-MS $m / z: 889\left(\mathrm{MNa}^{+}\right), 867\left(\mathrm{MH}^{+}\right) .{ }^{1} \mathrm{H}-\mathrm{NMR}\left(\mathrm{CDCl}_{3}\right) \delta:-0.27$, $-0.03,0.12$ (3H each), $0.14(6 \mathrm{H}), 0.15(3 \mathrm{H})\left(\mathrm{s}\right.$, three $\left.\mathrm{SiMe}_{2}\right), 0.75,0.94$, $0.96(9 \mathrm{H}$ each, s, three tert-Bu), $2.25[3 \mathrm{H}, \mathrm{s}, \mathrm{C}(6)-\mathrm{Me}], 3.41[2 \mathrm{H}, \mathrm{d}, J=5.9$ $\left.\mathrm{Hz}, \mathrm{C}(\gamma)-\mathrm{H}_{2}\right], 3.70\left(3 \mathrm{H}, \mathrm{s}, \mathrm{CCO}_{2} \mathrm{Me}\right), 3.79[1 \mathrm{H}, \mathrm{dd}, J=11.5,1.5 \mathrm{~Hz}$, one $\left.\mathrm{C}\left(5^{\prime}\right)-\mathrm{H}_{2}\right], 3.80\left(3 \mathrm{H}, \mathrm{s}, \mathrm{NCO}_{2} \mathrm{Me}\right), 3.83[1 \mathrm{H}, \mathrm{d}, J=6.8 \mathrm{~Hz}, \mathrm{C}(\beta)-\mathrm{OH}], 3.87$ $\left[1 \mathrm{H}, \mathrm{dd}, J=11.5,2.5 \mathrm{~Hz}\right.$, one $\left.\mathrm{C}\left(5^{\prime}\right)-\mathrm{H}_{2}\right], 4.11[3 \mathrm{H}$, s, overlapping with a $1 \mathrm{H}$ signal arising from $\left.\mathrm{C}\left(4^{\prime}\right)-\mathrm{H}, \mathrm{NMe}\right], 4.16[1 \mathrm{H}, \mathrm{m}, \mathrm{C}(\beta)-\mathrm{H}], 4.20[1 \mathrm{H}, \mathrm{d}$, $\left.J=4.4 \mathrm{~Hz}, \mathrm{C}\left(3^{\prime}\right)-\mathrm{H}\right], 4.41\left[1 \mathrm{H}, \mathrm{dd}, J=4.4,7.8 \mathrm{~Hz}, \mathrm{C}\left(2^{\prime}\right)-\mathrm{H}\right], 4.50[1 \mathrm{H}, \mathrm{m}$,
$\mathrm{C}(\alpha)-\mathrm{H}], 5.88[1 \mathrm{H}, \mathrm{d}, J=7.3 \mathrm{~Hz}, \mathrm{C}(\alpha)-\mathrm{NH}], 6.21\left[1 \mathrm{H}, \mathrm{d}, J=7.8 \mathrm{~Hz}, \mathrm{C}\left(1^{\prime}\right)-\right.$ $\mathrm{H}], 7.94[1 \mathrm{H}, \mathrm{s}, \mathrm{C}(2)-\mathrm{H}]$.

ii) Compound 26 ( $4 \mathrm{mg}, 0.004 \mathrm{mmol})$ was hydrogenated over Pearlman's catalyst $(4 \mathrm{mg})$ in $\mathrm{MeOH}(2 \mathrm{ml})$ at $40^{\circ} \mathrm{C}$ for $2 \mathrm{~h}$ and then at $50^{\circ} \mathrm{C}$ for a further $2 \mathrm{~h}$. The catalyst was filtered off and washed with hot $\mathrm{MeOH}(100 \mathrm{ml})$. The filtrate and washings were combined and concentrated in vacuo. The residue was purified by TLC on silica gel $\left[\mathrm{CHCl}_{3}-\mathrm{MeOH}(40: 1, \mathrm{v} / \mathrm{v})\right]$ to give $\mathbf{1 8}^{2)}(0.7 \mathrm{mg})$ and $27(1.5 \mathrm{mg})$ as a colorless glass.

$(\alpha S, \beta R)-\beta$-Hydroxy- $\alpha$ - $[($ methoxycarbonyl)amino]-4,6-dimethyl-9-oxo3- $\beta$-D-ribofuranosyl-4,9-dihydro-3 $\mathrm{H}$-imidazo $[1,2-a]$ purine-7-butanoic Acid Methyl Ester $[(\boldsymbol{\alpha} \boldsymbol{S}, \boldsymbol{\beta} \boldsymbol{R})-11]$ A $1 \mathrm{M} \mathrm{Bu}_{4} \mathrm{NF}$ solution $(0.7 \mathrm{ml}, 0.7$ $\mathrm{mmol})$ in THF was added to a solution of $17(58 \mathrm{mg}, 0.067 \mathrm{mmol})$ in pyridine-THF- $\mathrm{H}_{2} \mathrm{O}(1: 8: 1, \mathrm{v} / \mathrm{v})(3.3 \mathrm{ml})$, and the mixture was stirred at room temperature for $18 \mathrm{~h}$. The resulting solution was concentrated in vacuo. The residue was purified by flash chromatography $\left[\mathrm{CH}_{2} \mathrm{Cl}_{2}-\mathrm{MeOH}(5: 1, \mathrm{v} / \mathrm{v})\right]$ to give $(\alpha S, \beta R)-11 \cdot \mathrm{H}_{2} \mathrm{O}(31 \mathrm{mg}, 86 \%), \mathrm{mp} 173-183^{\circ} \mathrm{C}$. Recrystallization of this compound from $80 \%(\mathrm{v} / \mathrm{v})$ aqueous $\mathrm{MeOH}$ and drying over $\mathrm{P}_{2} \mathrm{O}_{5}$ at 2 $\mathrm{mmHg}$ and $50^{\circ} \mathrm{C}$ for $10 \mathrm{~h}$ afforded colorless plates, $\mathrm{mp} 205-210^{\circ} \mathrm{C}$. These were exposed to air at room temperature until a constant weight was reached, providing $(\alpha S, \beta R)-\mathbf{1 1} \cdot \mathrm{H}_{2} \mathrm{O}: \mathrm{mp} 198-210^{\circ} \mathrm{C}(\mathrm{dec}.) .[\alpha]_{\mathrm{D}}^{30}-72.8^{\circ}(c=$ $\left.0.167, \mathrm{H}_{2} \mathrm{O}\right)$. FAB-MS $m / z: 547\left(\mathrm{MNa}^{+}\right), 525\left(\mathrm{MH}^{+}\right) .{ }^{1} \mathrm{H}-\mathrm{NMR}\left[\left(\mathrm{CD}_{3}\right)_{2} \mathrm{SO}\right]$ $\delta: 2.07$ [3H, s, C(6)-Me], $3.10(\mathrm{dd}, J=14.2,6.8 \mathrm{~Hz}), 3.16(\mathrm{dd}, J=14.2,7 \mathrm{~Hz})$ [1H each, $\left.\mathrm{C}(\gamma)-\mathrm{H}_{2}\right], 3.53(0.3 \mathrm{H}, \mathrm{s}), 3.59[5.7 \mathrm{H}, \mathrm{s}$, overlapping with a $1 \mathrm{H}$ signal arising from one $\left.\mathrm{C}\left(5^{\prime}\right)-\mathrm{H}_{2}\right]$ (two $\mathrm{CO}_{2} \mathrm{Me}$ ), $3.69[1 \mathrm{H}$, ddd, $J=12.2,3.4$, $4.9 \mathrm{~Hz}$, one $\left.\mathrm{C}\left(5^{\prime}\right)-\mathrm{H}_{2}\right], 3.89(0.1 \mathrm{H}, \mathrm{br}), 3.94(0.9 \mathrm{H}, \mathrm{dd}, J=2.4,8.8 \mathrm{~Hz})[\mathrm{C}(\alpha)-$ $\mathrm{H}$ ], 3.99 [1H, ddd, $\left.J=3.4,3.4,4.9 \mathrm{~Hz}, \mathrm{C}\left(4^{\prime}\right)-\mathrm{H}\right], 4.03(3 \mathrm{H}, \mathrm{s}, \mathrm{NMe}), 4.13$ [1H, ddd, $\left.J=4.9,4.9,5.9 \mathrm{~Hz}, \mathrm{C}\left(3^{\prime}\right)-\mathrm{H}\right], 4.41[1 \mathrm{H}, \mathrm{dddd}, J=7,7,2.4,7.8 \mathrm{~Hz}$, $\mathrm{C}(\beta)-\mathrm{H}], 4.45\left[1 \mathrm{H}\right.$, ddd, $\left.J=4.9,5.9,4.9 \mathrm{~Hz}, \mathrm{C}\left(2^{\prime}\right)-\mathrm{H}\right], 4.97(0.9 \mathrm{H}), 5.01$ $(0.1 \mathrm{H})$ [d each, $J=7.8 \mathrm{~Hz}, \mathrm{C}(\beta)-\mathrm{OH}], 5.12\left[1 \mathrm{H}, \mathrm{dd}, J=5.4,4.9 \mathrm{~Hz}, \mathrm{C}\left(5^{\prime}\right)-\right.$ $\mathrm{OH}], 5.32\left[1 \mathrm{H}, \mathrm{d}, J=5.9 \mathrm{~Hz}, \mathrm{C}\left(3^{\prime}\right)-\mathrm{OH}\right], 5.71\left[1 \mathrm{H}, \mathrm{d}, J=5.9 \mathrm{~Hz}, \mathrm{C}\left(2^{\prime}\right)-\mathrm{OH}\right]$, $6.10\left[1 \mathrm{H}, \mathrm{d}, J=4.9 \mathrm{~Hz}, \mathrm{C}\left(1^{\prime}\right)-\mathrm{H}\right], 6.63(0.1 \mathrm{H}), 7.11(0.9 \mathrm{H})$ [d each, $J=8.8$ $\mathrm{Hz}, \mathrm{C}(\alpha)-\mathrm{NH}], 8.22[1 \mathrm{H}, \mathrm{s}, \mathrm{C}(2)-\mathrm{H}] .{ }^{1} \mathrm{H}-\mathrm{NMR}\left[\left(\mathrm{CD}_{3}\right)_{2} \mathrm{CO}\right] \delta^{24)}: 2.19[3 \mathrm{H}, \mathrm{s}$, $\mathrm{C}(6)-\mathrm{Me}], 3.28(\mathrm{dd}, J=14.7,5.9 \mathrm{~Hz}), 3.36(\mathrm{dd}, J=14.7,7 \mathrm{~Hz})[1 \mathrm{H}$ each, $\left.\mathrm{C}(\gamma)-\mathrm{H}_{2}\right], 3.68,3.69$ (3H each, s, $\mathrm{CCO}_{2} \mathrm{Me}$ and $\mathrm{NCO}_{2} \mathrm{Me}$ ), 3.85 (ddd, $J=12.2,5.4,2.9 \mathrm{~Hz}$ ), 3.94 (ddd, $J=12.2,4.9,2.9 \mathrm{~Hz}$ ) [1H each, $\mathrm{C}\left(5^{\prime}\right)-\mathrm{H}_{2}$, $4.21\left[1 \mathrm{H}, \mathrm{m}, \mathrm{C}\left(4^{\prime}\right)-\mathrm{H}\right], 4.22(3 \mathrm{H}, \mathrm{s}, \mathrm{NMe}), 4.26[1 \mathrm{H}, \mathrm{dd}, J=1.5,9.3 \mathrm{~Hz}$, $\mathrm{C}(\alpha)-\mathrm{H}], 4.49\left[2 \mathrm{H}, \mathrm{m}, \mathrm{C}\left(5^{\prime}\right)-\mathrm{OH}, \mathrm{C}\left(3^{\prime}\right)-\mathrm{H}\right], 4.57-4.67[2 \mathrm{H}, \mathrm{m}, \mathrm{C}(\beta)-\mathrm{OH}$, $\mathrm{C}(\beta)-\mathrm{H}], 4.74\left[1 \mathrm{H}, \mathrm{m}, \mathrm{C}\left(2^{\prime}\right)-\mathrm{H}\right], 4.78\left[1 \mathrm{H}, \mathrm{br}, \mathrm{C}\left(3^{\prime}\right)-\mathrm{OH}\right], 5.13[1 \mathrm{H}, \mathrm{br}$, $\left.\mathrm{C}\left(2^{\prime}\right)-\mathrm{OH}\right], 6.19$ [1H, d, $\left.J=9.3 \mathrm{~Hz}, \mathrm{C}(\alpha)-\mathrm{NH}\right], 6.30\left[1 \mathrm{H}, \mathrm{d}, J=4.9 \mathrm{~Hz}, \mathrm{C}\left(1^{\prime}\right)-\right.$ $\mathrm{H}$ ], 8.21 [1 $1 \mathrm{H}, \mathrm{s}, \mathrm{C}(2)-\mathrm{H}]$. Anal. Calcd for $\mathrm{C}_{21} \mathrm{H}_{28} \mathrm{~N}_{6} \mathrm{O}_{10} \cdot \mathrm{H}_{2} \mathrm{O}: \mathrm{C}, 46.49 ; \mathrm{H}$, 5.57; N, 15.49. Found: C, 46.40; H, 5.38; N, 15.41.

$(\alpha S, \beta S)-\beta$-Hydroxy- $\alpha$-[(methoxycarbonyl)amino]-4,6-dimethyl-9-oxo3- $\beta$-D-ribofuranosyl-4,9-dihydro-3 $\mathrm{H}$-imidazo $[1,2-a]$ purine-7-butanoic Acid Methyl Ester $[(\boldsymbol{\alpha} \boldsymbol{S}, \boldsymbol{\beta S})-\mathbf{1 1}] \quad$ Treatment of $27(37 \mathrm{mg}, 0.043 \mathrm{mmol})$ with $\mathrm{Bu}_{4} \mathrm{NF}$ and purification of the product were performed in manners similar to those described above for the preparation of $(\alpha S, \beta R)$-11, giving $(\alpha S, \beta S)-11(19 \mathrm{mg}, 86 \%)$ as a colorless glass. This was subjected to HPLC [LiChrosorb RP18 (7 $\mu \mathrm{m}, 250 \times 10 \mathrm{~mm})\left(\right.$ Merck); $\mathrm{MeOH}-\mathrm{H}_{2} \mathrm{O}(30: 70, \mathrm{v} / \mathrm{v})$ at the rate of $1.5 \mathrm{ml} / \mathrm{min}]$ in seven portions to give $(\alpha S, \beta S)-11 \cdot 3 / 2 \mathrm{H}_{2} \mathrm{O}(12$ $\mathrm{mg}, 50 \%), \mathrm{mp} 183-185^{\circ} \mathrm{C}$. Recrystallization of this compound from $90 \%$ (v/v) aqueous $\mathrm{MeOH}$, drying over $\mathrm{P}_{2} \mathrm{O}_{5}$ at $2 \mathrm{mmHg}$ and $50^{\circ} \mathrm{C}$ for $10 \mathrm{~h}$, and exposure to air at room temperature until a constant weight was reached, provided an analytical sample of $(\alpha S, \beta S)-\mathbf{1 1} \cdot 3 / 2 \mathrm{H}_{2} \mathrm{O}$ as colorless needles, $\mathrm{mp} 189^{\circ} \mathrm{C}$ (softened), $200-203^{\circ} \mathrm{C}$ (dec.). $[\alpha]_{\mathrm{D}}^{29}-38.3^{\circ}\left(c=0.174, \mathrm{H}_{2} \mathrm{O}\right)$. FAB-MS $m / z: 547\left(\mathrm{MNa}^{+}\right), 525\left(\mathrm{MH}^{+}\right)$. UV $\lambda_{\max }^{95 \% \mathrm{EtOH}} \mathrm{nm}(\varepsilon): 239.5$ (32300), 280 (sh) (5000), $298(6500) .{ }^{1} \mathrm{H}-\mathrm{NMR}\left[\left(\mathrm{CD}_{3}\right)_{2} \mathrm{SO}\right] \delta: 2.14[3 \mathrm{H}, \mathrm{s}$, C(6)-Me], 3.02 (dd, $J=14.7,7.5 \mathrm{~Hz}), 3.41$ (dd, $J=14.7,4.9 \mathrm{~Hz})[1 \mathrm{H}$ each, $\left.\mathrm{C}(\gamma)-\mathrm{H}_{2}\right], 3.55,3.58$ [3H each, s, overlapping with a $1 \mathrm{H}$ signal arising from one $\mathrm{C}\left(5^{\prime}\right)-\mathrm{H}_{2}, \mathrm{NCO}_{2} \mathrm{Me}$ and $\left.\mathrm{CCO}_{2} \mathrm{Me}\right], 3.68[1 \mathrm{H}$, ddd, $J=12,3.4,5.4 \mathrm{~Hz}$, one $\left.\mathrm{C}\left(5^{\prime}\right)-\mathrm{H}_{2}\right], 3.99$ [1H, ddd, $\left.J=3.4,3.4,4.4 \mathrm{~Hz}, \mathrm{C}\left(4^{\prime}\right)-\mathrm{H}\right], 4.04(3 \mathrm{H}, \mathrm{s}$, $\mathrm{NMe}), 4.09[1 \mathrm{H}, \mathrm{m}, \mathrm{C}(\beta)-\mathrm{H}], 4.11-4.16\left[2 \mathrm{H}, \mathrm{m}, \mathrm{C}(\alpha)-\mathrm{H}\right.$ and $\left.\mathrm{C}\left(3^{\prime}\right)-\mathrm{H}\right]$, $4.45\left[1 \mathrm{H}\right.$, ddd, $\left.J=4.4,5.9,4.9 \mathrm{~Hz}, \mathrm{C}\left(2^{\prime}\right)-\mathrm{H}\right], 5.06[1 \mathrm{H}, \mathrm{d}, J=5.4 \mathrm{~Hz}, \mathrm{C}(\beta)-$ $\mathrm{OH}], 5.12\left[1 \mathrm{H}, \mathrm{dd}, J=5.4 \mathrm{~Hz}\right.$ each, $\left.\mathrm{C}\left(5^{\prime}\right)-\mathrm{OH}\right], 5.31[1 \mathrm{H}, \mathrm{d}, J=5.4 \mathrm{~Hz}$, $\left.\mathrm{C}\left(3^{\prime}\right)-\mathrm{OH}\right], 5.70\left[1 \mathrm{H}, \mathrm{d}, J=5.9 \mathrm{~Hz}, \mathrm{C}\left(2^{\prime}\right)-\mathrm{OH}\right], 6.11[1 \mathrm{H}, \mathrm{d}, J=4.9 \mathrm{~Hz}$, $\left.\mathrm{C}\left(1^{\prime}\right)-\mathrm{H}\right], 6.86(0.1 \mathrm{H}, \mathrm{br}), 7.28(0.9 \mathrm{H}, \mathrm{d}, J=8.3 \mathrm{~Hz})[\mathrm{C}(\alpha)-\mathrm{NH}], 8.22[1 \mathrm{H}, \mathrm{s}$, $\mathrm{C}(2)-\mathrm{H}] .{ }^{1} \mathrm{H}-\mathrm{NMR}\left[\left(\mathrm{CD}_{3}\right)_{2} \mathrm{CO}\right] \delta^{24)}: 2.24[3 \mathrm{H}, \mathrm{s}, \mathrm{C}(6)-\mathrm{Me}], 3.18$ [1H, dd, $J=14.5,8.5 \mathrm{~Hz}$, one $\mathrm{C}(\gamma)-\mathrm{H}_{2}$ ] $, 3.65,3.66$ [3H each, s, overlapping with a $1 \mathrm{H}$ signal arising from one $\mathrm{C}(\gamma)-\mathrm{H}_{2}, \mathrm{CCO}_{2} \mathrm{Me}$ and $\mathrm{NCO}_{2} \mathrm{Me}$ ], 3.84 (ddd, $J=12.2,5.4,2.9 \mathrm{~Hz}$ ), 3.94 (ddd, $J=12.2,4.9,2.9 \mathrm{~Hz}$ ) [1H each, $\left.\mathrm{C}\left(5^{\prime}\right)-\mathrm{H}_{2}\right]$, $4.22\left[1 \mathrm{H}, \mathrm{m}, \mathrm{C}\left(4^{\prime}\right)-\mathrm{H}\right], 4.24(3 \mathrm{H}, \mathrm{s}, \mathrm{NMe}), 4.27[1 \mathrm{H}, \mathrm{m}, \mathrm{C}(\beta)-\mathrm{H}], 4.37[1 \mathrm{H}$, $\mathrm{m}, \mathrm{C}(\alpha)-\mathrm{H}], 4.44\left[1 \mathrm{H}, \mathrm{br}, \mathrm{C}\left(5^{\prime}\right)-\mathrm{OH}\right], 4.49\left[1 \mathrm{H}, \mathrm{m}, \mathrm{C}\left(3^{\prime}\right)-\mathrm{H}\right], 4.54[1 \mathrm{H}, \mathrm{d}$, $J=5.9 \mathrm{~Hz}, \mathrm{C}(\beta)-\mathrm{OH}], 4.65\left[1 \mathrm{H}, \mathrm{br}, \mathrm{C}\left(3^{\prime}\right)-\mathrm{OH}\right], 4.76\left[1 \mathrm{H}, \mathrm{m}, \mathrm{C}\left(2^{\prime}\right)-\mathrm{H}\right], 5.01$ $\left[1 \mathrm{H}, \mathrm{br}, \mathrm{C}\left(2^{\prime}\right)-\mathrm{OH}\right], 6.29\left[1 \mathrm{H}, \mathrm{d}, J=4.9 \mathrm{~Hz}, \mathrm{C}\left(1^{\prime}\right)-\mathrm{H}\right], 6.67[1 \mathrm{H}, \mathrm{d}, J=9.8 \mathrm{~Hz}$, $\mathrm{C}(\alpha)-\mathrm{NH}], 8.19$ [1H, s, C(2)-H]. Anal. Calcd for $\mathrm{C}_{21} \mathrm{H}_{28} \mathrm{~N}_{6} \mathrm{O}_{10} \cdot 3 / 2 \mathrm{H}_{2} \mathrm{O}: \mathrm{C}$, 
45.73; H, 5.67; N, 15.24. Found: C, 45.51; H, 5.38; N, 15.29.

Hydrolysis of $(\alpha S, \beta R)-11$ Leading to $(\alpha S, \beta R)-2$ A solution of $(\alpha S, \beta R)-\mathbf{1 1} \cdot \mathrm{H}_{2} \mathrm{O}(7 \mathrm{mg})$ in $0.1 \mathrm{~N}$ aqueous $\mathrm{HCl}(2 \mathrm{ml})$ was stored at room temperature for $1 \mathrm{~h}$, neutralized with $0.2 \mathrm{M}$ aqueous $\mathrm{Na}_{2} \mathrm{HPO}_{4}(2 \mathrm{ml})$, and concentrated in vacuo. The residue was purified by TLC on silica gel $\left[\mathrm{CHCl}_{3}-\mathrm{MeOH}(10: 1, \mathrm{v} / \mathrm{v})\right]$, providing $(\alpha S, \beta R)-2(5 \mathrm{mg}), \mathrm{mp} 232-235^{\circ} \mathrm{C}$ (dec.) [lit. ${ }^{3)} \mathrm{mp} 232-233.5^{\circ} \mathrm{C}$ (dec.)]. ${ }^{1} \mathrm{H}-\mathrm{NMR}\left(\mathrm{CDCl}_{3}\right)($ Table 1$) .{ }^{1} \mathrm{H}-$ NMR $\left[\left(\mathrm{CD}_{3}\right)_{2} \mathrm{CO}\right] \delta^{24)}: 2.21[3 \mathrm{H}, \mathrm{s}, \mathrm{C}(6)-\mathrm{Me}], 3.33[2 \mathrm{H}, \mathrm{d}, J=6.8 \mathrm{~Hz}, \mathrm{C}(\gamma)-$ $\mathrm{H}_{2}$ ], 3.68, 3.69 ( $3 \mathrm{H}$ each, s, $\mathrm{CCO}_{2} \mathrm{Me}$ and $\mathrm{NCO}_{2} \mathrm{Me}$ ), 3.88 (3H, s, NMe), $4.19(0.1 \mathrm{H}, \mathrm{br}), 4.30(0.9 \mathrm{H}, \mathrm{dd}, J=2.0,9.3 \mathrm{~Hz})[\mathrm{C}(\alpha)-\mathrm{H}], 4.51(0.9 \mathrm{H}, \mathrm{d}$, $J=5.9 \mathrm{~Hz}), 4.58(0.1 \mathrm{H}$, br) $[\mathrm{C}(\beta)-\mathrm{OH}], 4.62[1 \mathrm{H}, \mathrm{ddt}, J=2.0,5.9,6.8 \mathrm{~Hz}$, $\mathrm{C}(\beta)-\mathrm{H}], 5.74(0.1 \mathrm{H}, \mathrm{br}), 6.17(0.9 \mathrm{H}, \mathrm{d}, J=9.3 \mathrm{~Hz})[\mathrm{C}(\alpha)-\mathrm{NH}], 8.17[1 \mathrm{H}, \mathrm{d}$, $J=1.0 \mathrm{~Hz}, \mathrm{C}(2)-\mathrm{H}], 12.42[1 \mathrm{H}$, br, N(1)-H]. This sample was identical (by comparison of the IR and ${ }^{1} \mathrm{H}-\mathrm{NMR}$ spectra and TLC mobility) to an authentic sample ${ }^{3)}$ and optically pure on the basis of chiral HPLC analysis. ${ }^{16)}$

Hydrolysis of $(\alpha,, \beta S)-11$ leading to $(\alpha S, \beta S)-2$ Hydrolysis of $(\alpha S, \beta S)-\mathbf{1 1} \cdot 3 / 2 \mathrm{H}_{2} \mathrm{O}(2.1 \mathrm{mg})$ and purification of the product were performed in manners similar to those described above for the preparation of $(\alpha S, \beta R)-2$, providing $(\alpha S, \beta S)-2 \cdot 1 / 2 \mathrm{H}_{2} \mathrm{O}(1.5 \mathrm{mg}), \mathrm{mp} 230-233^{\circ} \mathrm{C}$ (dec.) [lit. ${ }^{3)} \mathrm{mp} 233-235^{\circ} \mathrm{C}$ (dec.)]. ${ }^{1} \mathrm{H}-\mathrm{NMR}\left(\mathrm{CDCl}_{3}\right)$ (Table 1). ${ }^{1} \mathrm{H}-\mathrm{NMR}$ $\left[\left(\mathrm{CD}_{3}\right)_{2} \mathrm{CO}\right] \delta^{24)}: 2.25[3 \mathrm{H}, \mathrm{s}, \mathrm{C}(6)-\mathrm{Me}], 3.17$ [1H, dd, $J=14.6,7.8 \mathrm{~Hz}$, one $\mathrm{C}(\gamma)-\mathrm{H}_{2}$ ], 3.63, 3.65 (3H each, s, two $\mathrm{CO}_{2} \mathrm{Me}$ ), 3.67 [1H, dd, $J=14.6,4.4$ $\mathrm{Hz}$, one $\left.\mathrm{C}(\gamma)-\mathrm{H}_{2}\right], 3.90$ (3H, s, NMe), 4.28 [1H, dddd, $J=7.8,4.4,5.9,6.4$ $\mathrm{Hz}, \mathrm{C}(\beta)-\mathrm{H}], 4.38$ [1H, dd, $J=5.9,8.3 \mathrm{~Hz}, \mathrm{C}(\alpha)-\mathrm{H}], 4.49[1 \mathrm{H}, \mathrm{d}, J=6.4 \mathrm{~Hz}$, $\mathrm{C}(\beta)-\mathrm{OH}], 6.25(0.1 \mathrm{H}, \mathrm{br}), 6.64(0.9 \mathrm{H}, \mathrm{d}, J=8.3 \mathrm{~Hz})[\mathrm{C}(\alpha)-\mathrm{NH}], 8.20[1 \mathrm{H}$, d, $J=1.0 \mathrm{~Hz}, \mathrm{C}(2)-\mathrm{H}], 12.50[1 \mathrm{H}, \mathrm{br}, \mathrm{N}(1)-\mathrm{H}] .{ }^{1} \mathrm{H}-\mathrm{NMR}\left[\mathrm{CD}_{3} \mathrm{CN}\right] \delta^{25)}: 2.20$ [3H, s, C(6)-Me], $3.08(1 \mathrm{H}, \mathrm{dd}, J=15.1,8.3 \mathrm{~Hz}), 3.54(1 \mathrm{H}, \mathrm{dd}, J=15.1,4.4$ $\mathrm{Hz}),\left[\mathrm{C}(\gamma)-\mathrm{H}_{2}\right], 3.63,3.65$ (3H each, s, $\mathrm{CCO}_{2} \mathrm{Me}$ and $\left.\mathrm{NCO}_{2} \mathrm{Me}\right), 3.71[1 \mathrm{H}, \mathrm{d}$, $J=6.4 \mathrm{~Hz}, \mathrm{C}(\beta)-\mathrm{OH}], 3.84(3 \mathrm{H}, \mathrm{s}, \mathrm{NMe}), 4.15[1 \mathrm{H}, \mathrm{m}, \mathrm{C}(\beta)-\mathrm{H}], 4.29[1 \mathrm{H}$, $\mathrm{m}, \mathrm{C}(\alpha)-\mathrm{H}], 6.32[1 \mathrm{H}, \mathrm{br}, \mathrm{C}(\alpha)-\mathrm{NH}], 7.94[1 \mathrm{H}, \mathrm{s}, \mathrm{C}(2)-\mathrm{H}], 11.09$ [1H, br, $\mathrm{N}(1)-\mathrm{H}] .{ }^{1} \mathrm{H}-\mathrm{NMR}$ (pyridine- $d_{5}$ ) $\delta^{26)}: 2.47$ [3H, s, C(6)-Me], $3.61[1 \mathrm{H}, \mathrm{dd}$, $J=14.7,8.3 \mathrm{~Hz}$, one $\left.\mathrm{C}(\gamma)-\mathrm{H}_{2}\right], 3.64,3.66$ (3H each, s, two $\left.\mathrm{CO}_{2} \mathrm{Me}\right), 3.70$ $[1 \mathrm{H}, \mathrm{m}, \mathrm{C}(\beta)-\mathrm{H}], 3.91(3 \mathrm{H}, \mathrm{s}, \mathrm{NMe}), 4.14[1 \mathrm{H}, \mathrm{dd}, J=14.7,3.9 \mathrm{~Hz}$, one $\left.\mathrm{C}(\gamma)-\mathrm{H}_{2}\right], 5.16[1 \mathrm{H}, \mathrm{dd}, J=6.4,7.8 \mathrm{~Hz}, \mathrm{C}(\alpha)-\mathrm{H}], 8.33$ [1H, s, C(2)-H], 8.57 $[1 \mathrm{H}, \mathrm{d}, J=7.8 \mathrm{~Hz}, \mathrm{C}(\alpha)-\mathrm{NH}]$. This sample was identical (by comparison of the IR and ${ }^{1} \mathrm{H}-\mathrm{NMR}$ spectra and TLC mobility) to an authentic sample ${ }^{3)}$ and optically pure on the basis of chiral HPLC analysis. ${ }^{16)}$

$(\alpha S, \beta R)-\beta$-(Acetoxy- $\left.d_{3}\right)-\alpha-[($ methoxycarbonyl)amino]-4,6-dimethyl-9oxo-3-[2,3,5-tri- $O$-(acetyl- $\left.d_{3}\right)$ - $\beta$-D-ribofuranosyl]-4,9-dihydro-3H-imidazo[1,2-a]purine-7-butanoic Acid Methyl Ester (28) Compound $(\alpha S, \beta R)-11(5 \mathrm{mg})$ was treated in a manner similar to that described below for the preparation of 29, giving $28(6 \mathrm{mg})$ as a colorless glass, MS m/z: 704 $\left(\mathrm{M}^{+}\right) .{ }^{1} \mathrm{H}-\mathrm{NMR}\left(\mathrm{CDCl}_{3}\right) \delta: 2.21$ [3H, s, C $\left.(6)-\mathrm{Me}\right], 3.09$ [1H, dd, $J=15.1,9.8$ $\mathrm{Hz}$, one $\left.\mathrm{C}(\gamma)-\mathrm{H}_{2}\right], 3.71,3.75\left(3 \mathrm{H}\right.$ each, s, $\mathrm{NCO}_{2} \mathrm{Me}$ and $\left.\mathrm{CCO}_{2} \mathrm{Me}\right), 3.78$ $\left[1 \mathrm{H}, \mathrm{dd}, J=15.1,2.9 \mathrm{~Hz}\right.$, one $\left.\mathrm{C}(\gamma)-\mathrm{H}_{2}\right], 4.12(3 \mathrm{H}, \mathrm{s}, \mathrm{NMe}), 4.32[2 \mathrm{H}, \mathrm{d}$, $\left.J=2.4 \mathrm{~Hz}, \mathrm{C}\left(5^{\prime}\right)-\mathrm{H}_{2}\right], 4.49$ [1H, dt, $\left.J=2.4,2.9 \mathrm{~Hz}, \mathrm{C}\left(4^{\prime}\right)-\mathrm{H}\right], 4.63(0.1 \mathrm{H}, \mathrm{br})$, $4.67(0.9 \mathrm{H}, \mathrm{dd}, J=9.8,2.9 \mathrm{~Hz})[\mathrm{C}(\alpha)-\mathrm{H}], 5.28(0.1 \mathrm{H}, \mathrm{br}), 5.54(0.9 \mathrm{H}, \mathrm{d}$, $J=9.8 \mathrm{~Hz})[\mathrm{C}(\alpha)-\mathrm{NH}], 5.50\left[1 \mathrm{H}, \mathrm{dd}, J=2.9,5.4 \mathrm{~Hz}, \mathrm{C}\left(3^{\prime}\right)-\mathrm{H}\right], 5.80[1 \mathrm{H}$, ddd, $J=9.8,2.9,2.9 \mathrm{~Hz}, \mathrm{C}(\beta)-\mathrm{H}], 5.85\left[1 \mathrm{H}, \mathrm{dd}, J=5.4,6.3 \mathrm{~Hz}, \mathrm{C}\left(2^{\prime}\right)-\mathrm{H}\right]$, $6.18\left[1 \mathrm{H}, \mathrm{d}, J=6.3 \mathrm{~Hz}, \mathrm{C}\left(1^{\prime}\right)-\mathrm{H}\right], 7.74[1 \mathrm{H}, \mathrm{s}, \mathrm{C}(2)-\mathrm{H}]$.

$(\alpha S, \beta S)-\beta$ - Acetoxy- $\left.d_{3}\right)-\alpha-[($ methoxycarbonyl)amino]-4,6-dimethyl-9oxo-3-[2,3,5-tri- $O$-(acetyl- $\left.d_{3}\right)$ - $\beta$-D-ribofuranosyl]-4,9-dihydro-3H-imidazo[1,2-a]purine-7-butanoic Acid Methyl Ester (29) A solution of $(\alpha S, \beta S)-11(5 \mathrm{mg})$ in a mixture of $\mathrm{Ac}_{2} \mathrm{O}-d_{6}(47 \mathrm{mg})$ and pyridine $(102 \mathrm{mg})$ was allowed to stand at room temperature for $1.5 \mathrm{~h}$ and then concentrated in vacuo. The residue was purified by TLC on silica gel $\left[\mathrm{CHCl}_{3}-\mathrm{MeOH}(30: 1\right.$, $\mathrm{v} / \mathrm{v})$ ], giving $29(6 \mathrm{mg})$ as a colorless glass, MS m/z: $704\left(\mathrm{M}^{+}\right) .{ }^{1} \mathrm{H}-\mathrm{NMR}$ $\left(\mathrm{CDCl}_{3}\right) \delta: 2.24[3 \mathrm{H}, \mathrm{s}, \mathrm{C}(6)-\mathrm{Me}], 3.01[1 \mathrm{H}, \mathrm{dd}, J=15.1,8.8 \mathrm{~Hz}$, one $\mathrm{C}(\gamma)-$ $\mathrm{H}_{2}$ ] $, 3.69,3.70$ ( $3 \mathrm{H}$ each, s, $\mathrm{NCO}_{2} \mathrm{Me}$ and $\mathrm{CCO}_{2} \mathrm{Me}$ ), 3.89 [1H, dd, $J=15.1$, $4.4 \mathrm{~Hz}$, one $\left.\mathrm{C}(\gamma)-\mathrm{H}_{2}\right], 4.11(3 \mathrm{H}, \mathrm{s}, \mathrm{NMe}), 4.32\left[2 \mathrm{H}, \mathrm{m}, \mathrm{C}\left(5^{\prime}\right)-\mathrm{H}_{2}\right], 4.50[1 \mathrm{H}$, $\left.\mathrm{m}, \mathrm{C}\left(4^{\prime}\right)-\mathrm{H}\right], 4.71[1 \mathrm{H}, \mathrm{dd}, J=5.4,8.8 \mathrm{~Hz}, \mathrm{C}(\alpha)-\mathrm{H}], 5.48[1 \mathrm{H}, \mathrm{dd}, J=3.4,5.4$ $\left.\mathrm{Hz}, \mathrm{C}\left(3^{\prime}\right)-\mathrm{H}\right], 5.50[1 \mathrm{H}, \mathrm{m}, \mathrm{C}(\beta)-\mathrm{H}], 5.83$ [1H, dd, $\left.J=5.4,6.4 \mathrm{~Hz}, \mathrm{C}\left(2^{\prime}\right)-\mathrm{H}\right]$, $6.12[1 \mathrm{H}, \mathrm{d}, J=8.8 \mathrm{~Hz}, \mathrm{C}(\alpha)-\mathrm{NH}], 6.19\left[1 \mathrm{H}, \mathrm{d}, J=6.4 \mathrm{~Hz}, \mathrm{C}\left(1^{\prime}\right)-\mathrm{H}\right], 7.74$ $[1 \mathrm{H}, \mathrm{s}, \mathrm{C}(2)-\mathrm{H}]$

Isolation of $\boldsymbol{\beta}$-Hydroxywybutine Unfractionated tRNA was obtained as described below according to the reported procedure. ${ }^{27)}$ Twenty female Wistar rats were decapitated and their livers $(160 \mathrm{~g})$ removed and quickly chilled in ice. Batches of $9 \mathrm{~g}$ were homogenized with $88 \%(\mathrm{v} / \mathrm{v})$ aqueous phenol $(14 \mathrm{ml})$ and Tris buffer $\left[0.02 \mathrm{M}\left(\mathrm{HOCH}_{2}\right)_{3} \mathrm{CNH}_{2}-\mathrm{HCl}(\mathrm{pH} 7.5)\right.$ containing $1 \mathrm{M} \mathrm{NaCl}-0.5 \mathrm{~mm}$ ethylenediaminetetraacetic acid-0.01 $\left.\mathrm{M} \mathrm{MgCl}_{2}\right]$ (14 $\mathrm{ml}$ ) in a homogenizer at high speed for $2-3 \mathrm{~min}$. The combined homogenate was shaken at room temperature for $2 \mathrm{~h}$ and centrifuged $(8000$ $\mathrm{rpm}, 40 \mathrm{~min})$ at $4{ }^{\circ} \mathrm{C}$. The precipitate was mixed with the Tris buffer $(150$ $\mathrm{ml}$ ) and centrifuged. EtOH (1.41) was added to the combined supernatant (ca. $700 \mathrm{ml}$ ), and the whole was stored at $4^{\circ} \mathrm{C}$ overnight. The precipitate that separated was collected by centrifugation at $4{ }^{\circ} \mathrm{C}$ and suspended in $0.3 \mathrm{M}$ aqueous AcONa $(140 \mathrm{ml})$. The mixture was stirred at room temperature for $10 \mathrm{~min}$ after the addition of $\mathrm{Me}_{2} \mathrm{CHOH}(56 \mathrm{ml})$ and centrifuged at $20^{\circ} \mathrm{C}$. The precipitate was again treated with $0.3 \mathrm{M}$ aqueous $\mathrm{AcONa}(80 \mathrm{ml})$ and $\mathrm{Me}_{2} \mathrm{CHOH}(40 \mathrm{ml})$, and the mixture was centrifuged at $20^{\circ} \mathrm{C}$. The combined supernatant was cooled with ice for $1 \mathrm{~h}$ after the addition of $\mathrm{Me}_{2} \mathrm{CHOH}$ (130 $\mathrm{ml}$ ), and the precipitate was collected by centrifugation. The precipitate thus obtained was washed successively with $67 \%$ (v/v) aqueous EtOH (containing $\left.0.1 \mathrm{M} \mathrm{NaCl}-0.005 \mathrm{M} \mathrm{MgCl}_{2}\right)$, EtOH, and $\mathrm{Et}_{2} \mathrm{O}(10 \mathrm{ml}$ each), and dried over $\mathrm{P}_{2} \mathrm{O}_{5}$ under reduced pressure, giving crude tRNA $(184 \mathrm{mg})$. A portion of this product $\left(100 \mathrm{mg}, 1000 \mathrm{~A}_{260}\right.$ units) was dissolved in $\mathrm{H}_{2} \mathrm{O}(15 \mathrm{ml})$, and the solution $(\mathrm{pH} 8.9)$ was brought to $\mathrm{pH} 2.9$ by the addition of dilute aqueous $\mathrm{HCl}$. The resulting mixture was stirred at $40{ }^{\circ} \mathrm{C}$ for $16 \mathrm{~h}$ and centrifuged at $4{ }^{\circ} \mathrm{C}$. After the addition of $\mathrm{EtOH}(30 \mathrm{ml})$ the supernatant was centrifuged at $4{ }^{\circ} \mathrm{C}$. The supernatant was neutralized with $\mathrm{NaHCO}_{3}$, and the precipitate that resulted was removed by centrifugation at $4{ }^{\circ} \mathrm{C}$. The supernatant was concentrated in vacuo, and the residue was purified by TLC on silica gel $\left[\mathrm{CHCl}_{3}-\mathrm{MeOH}(10: 1, \mathrm{v} / \mathrm{v})\right]$, giving the minor base. The HPLC [LiChrosorb Si 60 (Merck); $\left.\mathrm{CHCl}_{3}-\mathrm{MeOH}(95: 5, \mathrm{v} / \mathrm{v})\right]$ and chiral $\mathrm{HPLC}^{16}$ ) behavior of this substance was identical to that of $(\alpha S, \beta S)-2$. The observable ${ }^{1} \mathrm{H}-\mathrm{NMR}$ signals $\left[\left[\left(\mathrm{CD}_{3}\right)_{2} \mathrm{CO}\right] \delta^{24)}: 2.25(\mathrm{~s}), 3.63(\mathrm{~s}), 3.65(\mathrm{~s}), 3.90(\mathrm{~s}), 4.48(\mathrm{~d}, J=6.4\right.$ $\mathrm{Hz}), 6.64(\mathrm{~d}, J=8 \mathrm{~Hz}), 8.20(\mathrm{~s}), 12.50(\mathrm{br})]$ were superimposable on those obtained for a dilute solution of $(\alpha S, \beta S)-2$.

Isolation and Identification of $\boldsymbol{\beta}$-Hydroxywybutosine Crude tRNA ( $1 \mathrm{~g}, 10000 \mathrm{~A}_{260}$ units) was produced in five batches of 20 rats in a manner similar to that described above. This was extracted with a mixture of $0.3 \mathrm{M}$ aqueous $\mathrm{AcONa}(75 \mathrm{ml})$ and $\mathrm{Me}_{2} \mathrm{CHOH}(30 \mathrm{ml})$ and then with a mixture of $0.3 \mathrm{M}$ aqueous AcONa $(42 \mathrm{ml})$ and $\mathrm{Me}_{2} \mathrm{CHOH}(21 \mathrm{ml})$. The extracts were combined, centrifuged, and diluted with $\mathrm{Me}_{2} \mathrm{CHOH}(70 \mathrm{ml})$. The resulting precipitate was collected by centrifugation at $4{ }^{\circ} \mathrm{C}$ after cooling with ice, washed successively with $\mathrm{EtOH}$ and $\mathrm{Et}_{2} \mathrm{O}$, and dried to give the first crop of tRNA $(520 \mathrm{mg})$. The residue, which remained undissolved on extraction with a mixture of aqueous $\mathrm{AcONa}$ and $\mathrm{Me}_{2} \mathrm{CHOH}$, was further extracted with $0.3 \mathrm{M}$ aqueous AcONa $(2 \times 28 \mathrm{ml})$. The extracts were collected by centrifugation, diluted with $\mathrm{Me}_{2} \mathrm{CHOH}(58 \mathrm{ml})$, and chilled with ice. The resulting precipitate was collected by centrifugation at $4{ }^{\circ} \mathrm{C}$, providing a second crop of tRNA $(210 \mathrm{mg})$. These crops were combined and extracted twice with the Tris buffer $(20 \mathrm{ml}$ and $10 \mathrm{ml})$ described above. The extracts were collected by centrifugation at $20^{\circ} \mathrm{C}$ and subjected to a column packed with ion-exchange cellulose (Whatman DE 32) (wet volume $50 \mathrm{ml}$ ) which had been equilibrated with the Tris buffer. The column was washed with the Tris buffer $(140 \mathrm{ml})$ followed by elution with the Tris buffer $(800 \mathrm{ml})$ containing $1 \mathrm{M} \mathrm{NaCl}$. EtOH (1.51) was added to the eluate and the mixture was stored at $4{ }^{\circ} \mathrm{C}$ overnight. The resulting precipitate was collected by centrifugation at $4{ }^{\circ} \mathrm{C}$, washed successively with $67 \%(\mathrm{v} / \mathrm{v})$ aqueous EtOH (containing $0.1 \mathrm{M}$ $\left.\mathrm{NaCl}-0.005 \mathrm{M} \mathrm{MgCl}_{2}\right), \mathrm{EtOH}$, and $\mathrm{Et}_{2} \mathrm{O}$ ( $30 \mathrm{ml}$ each), and dried over $\mathrm{P}_{2} \mathrm{O}_{5}$ under reduced pressure, providing tRNA $(355 \mathrm{mg})$.

A portion of this product $\left(350 \mathrm{mg}, 5300 \mathrm{~A}_{260}\right.$ units) was treated with nuclease $\mathrm{P}_{1}$ (Yamasa) (500 units) in $0.02 \mathrm{M}$ acetate buffer $(\mathrm{pH} 5.35,30 \mathrm{ml}$ ) at $50{ }^{\circ} \mathrm{C}$ for $3 \mathrm{~h}$. The hydrolysate was subjected to column chromatography on Cosmosil $140 \mathrm{C}_{18}-\mathrm{OPN}$ (Nacalai Tesque) $(10 \mathrm{~g})\left[\mathrm{H}_{2} \mathrm{O}(80 \mathrm{ml})\right.$ and then $\left.\mathrm{MeOH}-\mathrm{H}_{2} \mathrm{O}(30: 70, \mathrm{v} / \mathrm{v})\right]$ in two portions. The $\mathrm{MeOH}-\mathrm{H}_{2} \mathrm{O}$ fractions $(80$ $\mathrm{ml})$ were combined and concentrated in vacuo to leave a yellow glass (210 $\mathrm{A}_{260}$ units). It was dissolved in $\mathrm{H}_{2} \mathrm{O}(3.9 \mathrm{ml})$, and a solution of nuclease $\mathrm{P}_{1}$ (2000 units) in $0.02 \mathrm{M}$ acetate buffer $(\mathrm{pH} 5.35,4.7 \mathrm{ml}$ ) was added. The whole was stored at $50{ }^{\circ} \mathrm{C}$ for $3 \mathrm{~h}$ and then $0.02 \mathrm{~N}$ aqueous $\mathrm{NaOH}(1.05 \mathrm{ml})$ and Escherichia coli alkaline phosphatase (Takara Shuzo) (6.4 units) were added. The mixture ( $\mathrm{pH}$ 9) was stored at $50^{\circ} \mathrm{C}$ for $1 \mathrm{~h}$ and concentrated in vacuo. This was dissolved in $\mathrm{H}_{2} \mathrm{O}(8 \mathrm{ml})$ and purified by HPLC [LiChrosorb $\mathrm{RP} 18(7 \mu \mathrm{m}, 250 \times 10 \mathrm{~mm})$ (Merck); $\left.\mathrm{MeOH}-\mathrm{H}_{2} \mathrm{O}(30: 70, \mathrm{v} / \mathrm{v})\right]$ in seven portions, providing the target nucleoside $\left(1.5 \mathrm{~A}_{310}\right.$ unit, ca. $\left.100 \mu \mathrm{g}\right)$, of which HPLC behavior was identical to that of $(\alpha S, \beta S)-11$.

The nucleoside was dissolved in a mixture of $\mathrm{Ac}_{2} \mathrm{O}-d_{6}(29 \mathrm{mg})$ and pyridine $(69 \mathrm{mg})$, stored at room temperature for $1.5 \mathrm{~h}$, and purified by TLC on silica gel $\left[\mathrm{CH}_{2} \mathrm{Cl}_{2}-\mathrm{MeOH}(30: 1, \mathrm{v} / \mathrm{v})\right]$ to afford the tetraacetate- $d_{12}$, MS $\mathrm{m} / z$ (\%): $704\left(\mathrm{M}^{+}\right)(7), 641$ (3), 609 (18), 582 (12), 550 (2), 483 (18), 437 (3), 374 (2), 342 (22), 315 (14), 283 (12), 268 (9), 216 (100), 142 (26). ${ }^{1} \mathrm{H}-\mathrm{NMR}$ $\left(\mathrm{CDCl}_{3}\right) \delta: 2.24(3 \mathrm{H}, \mathrm{s}), 3.02(1 \mathrm{H}, \mathrm{dd}), 3.697,3.704(3 \mathrm{H}$ each, s), $4.11(3 \mathrm{H}$, s), $4.33(2 \mathrm{H}, \mathrm{m}), 4.50(1 \mathrm{H}, \mathrm{m}), 4.71(1 \mathrm{H}, \mathrm{dd}), 5.48(1 \mathrm{H}, \mathrm{dd}), 5.51(1 \mathrm{H}, \mathrm{m})$, $5.83(1 \mathrm{H}, \mathrm{dd}), 6.12(1 \mathrm{H}, \mathrm{d}), 6.19(1 \mathrm{H}, \mathrm{d}), 7.74(1 \mathrm{H}, \mathrm{s})$. This compound was identical (by comparison of the MS and ${ }^{1} \mathrm{H}-\mathrm{NMR}$ spectra) to 29.

A solution of half of the tetraacetate- $d_{12}$ in $0.1 \mathrm{M} \mathrm{MeONa}-\mathrm{MeOH}(0.1 \mathrm{ml})$ was stored at $0{ }^{\circ} \mathrm{C}$ for $5 \mathrm{~min}$ and $0.1 \mathrm{~N}$ aqueous $\mathrm{HCl}(0.2 \mathrm{ml})$ was added at 
once. The resulting solution was stored at room temperature for $1 \mathrm{~h}$, neutralized by the addition of $0.2 \mathrm{M} \mathrm{Na}_{2} \mathrm{HPO}_{4}(0.1 \mathrm{ml})$, and concentrated in vacuo. The residue was purified by TLC on silica gel $\left[\mathrm{CHCl}_{3}-\mathrm{MeOH}(10: 1, \mathrm{v} / \mathrm{v})\right]$, giving the base, ${ }^{1} \mathrm{H}-\mathrm{NMR}\left[\left(\mathrm{CD}_{3}\right)_{2} \mathrm{CO}\right] \delta^{24)}: 2.25(3 \mathrm{H}, \mathrm{s}), 3.18(1 \mathrm{H}, \mathrm{dd}), 3.64$, $3.65(3 \mathrm{H}$ each, s), $3.67(1 \mathrm{H}, \mathrm{dd}), 3.90(3 \mathrm{H}, \mathrm{s}), 4.28(\mathrm{~m}), 4.39(1 \mathrm{H}, \mathrm{m}), 4.47$ $(1 \mathrm{H}, \mathrm{d}), 6.62(\mathrm{~d}), 8.20(1 \mathrm{H}, \mathrm{s}), 12.50(1 \mathrm{H}, \mathrm{br})$. This compound was identical (by comparison of the ${ }^{1} \mathrm{H}-\mathrm{NMR}$ spectrum and chiral HPLC ${ }^{16)}$ mobility) to $(\alpha S, \beta S)-\mathbf{2}$.

Acknowledgments This work was supported in part by a grant from the Japan Research Foundation for Optically Active Compounds. We are grateful to Professor Ken-ichi Miyamoto (Kanazawa University) and his associates for providing rat livers. We are also indebted to Professor Masashi Ohba (Kanazawa University) for assignment of ${ }^{1} \mathrm{H}-\mathrm{NMR}$ spectra $\left(\mathrm{CDCl}_{3}\right)$ of $(\alpha S, \beta R)-$ and $(\alpha S, \beta S)-2$.

\section{References and Notes}

1) Itaya T., Kanai T., Sawada T., Chem. Pharm. Bull., 50, 547-548 (2002).

2) Itaya T., Kanai T., Iida T., Chem. Pharm. Bull., 50, 530-533 (2002).

3) Itaya T., Watanabe N., Iida T., Kanai T., Mizutani A., Tetrahedron, 51, 6419-6430 (1995)

4) Itaya T., Morisue M., Takeda M., Kumazawa Y., Chem. Pharm. Bull., 38, 2656-2661 (1990).

5) References cited in refs. $1-4$.

6) Nakanishi K., Blobstein S., Funamizu M., Furutachi N., Van Lear G., Grunberger D., Lanks K. W., Weinstein I. B., Nature, New Biol., 234, 107-109 (1971).

7) Blobstein S. H., Grunberger D., Weinstein I. B., Nakanishi K., Biochemistry, 12, 188-193 (1973).

8) Nakanishi K., Furutachi N., Funamizu M., Grunberger D., Weinstein I.
B., J. Am. Chem. Soc., 92, 7617-7619 (1970).

9) Thiebe R., Zachau H. G., Baczynskyj L., Biemann K., Sonnenbichler J., Biochim. Biophys. Acta, 240, 163-169 (1971).

10) Feinberg A. M., Nakanishi K., Barciszewski J., Rafalski A. J., Augustyniak H., Wiewiórowski M., J. Am. Chem. Soc., 96, 7797-7800 (1974).

11) Yoshikami D., Keller E. B., Biochemistry, 10, 2969-2976 (1971).

12) Kasai H., Yamaizumi Z., Kuchino Y., Nishimura S., Nucleic Acids Res., 6, 993-999 (1979).

13) Mochizuki A., Omata Y., Miyazawa Y., Bull. Chem. Soc. Jpn., 53, 813-814 (1980).

14) Barciszewska M., Kaminek M., Barciszewski J., Wiewiórowski M., Plant Sci. Lett., 20, 387-392 (1981).

15) Itaya T., Watanabe N., Mizutani A., Tetrahedron Lett., 27, 4043-4046 (1986).

16) Itaya T., Kanai T., Chem. Pharm. Bull., 46, 1220-1224 (1998).

17) Itaya T., Kanai T., Iida T., Tetrahedron Lett., 38, 1979-1982 (1997).

18) Itaya T., Kanai T., Tetrahedron Lett., 40, 8003-8006 (1999).

19) Itaya T., Morisue M., Shimomichi M., Ozasa M., Shimizu S., Nakagawa S., J. Chem. Soc., Perkin Trans. 1, 1994, 2759-2765.

20) Itaya T., Shimizu S., Chem. Pharm. Bull., 43, 398- 402 (1995).

21) Riley J. H., Sopher D. W., Utley J. H. P., Walton D. J., J. Chem. Res. $(S)$, 1982, 326-327.

22) Ogilvie K. K., Beaucage S. L., Schifman A. L., Theriault N. Y., Sadana K. L., Can. J. Chem., 56, 2768-2780 (1978).

23) Thiebe R., Zachau H. G., Eur. J. Biochem., 5, 546-555 (1968).

24) The residual peak at 2.09 was used as a reference.

25) The residual peak at 1.96 was used as a reference.

26) The residual $\mathrm{C}(3)-\mathrm{H}$ peak at 7.55 was used as a reference.

27) Nishimura S., "Proceedings of Nucleic Acid Research," Vol. 2, ed. by Cantoni G. L., Harper and Row, New York, 1971, pp. 542-564. 